\title{
Biochar - a Panacea for Agriculture or Just Carbon?
}

\section{Elvir Tenic", Rishikesh Ghogare* and Amit Dhingra ${ }^{1}$,}

1 Affiliation 1; elvir.tenic@wsu.edu, Department of Horticulture, Washington State University, Pullman, WA USA

2 Affiliation 2; rishikesh.ghogare@wsu.edu, Department of Horticulture, Washington State University, Pullman, WA USA

* These authors contributed equally to this work

§ Correspondence: adhingra@wsu.edu; Department of Horticulture, Washington State University, Pullman, WA USA

\begin{abstract}
The sustainable production of food faces formidable challenges. Foremost is the availability of arable soils, which have been ravaged by the overuse of fertilizers and detrimental soil management techniques. As such, maintenance of soil quality, and reclamation of marginal soils, has become an increasingly important endeavor. Recently, there has been emerging interest in the use of biochar, a carbon rich, porous material thought to improve various aspects of soil performance. Biochar (BC) is produced through the thermochemical decomposition of organic matter at high temperature in an oxygen limited environment, in a process known as pyrolysis. Importantly, the source of organic material, or 'feedstock,' used in this process and different parameters of pyrolysis, especially temperature, determine the chemical and physical properties of biochar. Incorporation of $\mathrm{BC}$ impacts soil-water relations, tilth and nutrient status, $\mathrm{pH}$, soil organic matter (SOM), and microbial activity. Soil amendment with $\mathrm{BC}$ has been shown to have an overall positive impact on soil health and crop productivity; however, initial soil properties need to be considered prior to the application of BC. There is an urgent need to understand the effects of long-term field application of $\mathrm{BC}$ and how it influences the soil microcosm. This knowledge will facilitate predictable enhancement of crop productivity and meaningful carbon sequestration.
\end{abstract}

Abbreviations: BC - biochar, SOM - soil organic matter, GHG - greenhouse gas, CEC - cation exchange capacity, FTIR - Fourier transform infrared spectroscopy, SBBC - sugarcane bagasse biochar, $\mathrm{C}$ - carbon, $\mathrm{N}$ - nitrogen, $\mathrm{P}$ - phosphorous, $\mathrm{K}$ - potassium, $\mathrm{Ca}$ - calcium, $\mathrm{Mg}$ - magnesium, $\mathrm{Fe}$ - iron, $\mathrm{Na}$ - sodium, $\mathrm{Si}$ - silicon, $\mathrm{Cd}$ - cadmium, $\mathrm{Cu}$ - copper, $\mathrm{Ni}$ - nickel, $\mathrm{Pb}$ - lead, $\mathrm{Zn}$ - zinc

Keywords: agronomy; sustainability; organic fertilizer; crop productivity; soil acidification; soil organic matter; pyrolysis; microbial activity

\section{Introduction}

"If you desire peace, cultivate justice, but at the same time cultivate the fields to produce more bread; otherwise there will be no peace" Norman Borlaug, Oslo, Norway, December 11, 1970. Nobel lecture.

What was prevalent in the 1960s holds true yet again - the world stands at a threshold where the availability of food is threatened, albeit for reasons different than six decades ago. The changing climate, deteriorating land and water conditions, and loss of biodiversity present unprecedented challenges for humankind [1]. At present, greenhouse gas (GHG) emissions are increasing rapidly, with carbon dioxide $\left(\mathrm{CO}_{2}\right)$ levels rising more than $3 \%$ annually since the 2000s. These GHG discharges have a drastic impact on the climate, despite global efforts to reduce the emissions over the last few 
decades [2]. As a step towards reducing GHG emissions, more than 100 countries signed and ratified the Paris Climate Agreement, aiming to limit the increase in global temperature to $1.5-2^{\circ} \mathrm{C}$ over the next 30 years [3]. Achievement of this target requires swift adoption of carbon-neutral and carbonnegative technologies to limit the global GHG emissions to approximately 9.8 gigatons of carbon $[4,5]$. Several approaches are being considered for $\mathrm{CO}_{2}$ removal from the atmosphere, such as the adoption of bioenergy, direct carbon capture, afforestation and reforestation, modification of agricultural practices, use of bioenergy, and direct infusion of recalcitrant carbon into the soil using biochar (BC) [6-9]. Longer-term sequestration of carbon into the soil using biochar is one of the potential carbonnegative approaches. As soils can store twice as much carbon compared to atmospheric reserves and for longer periods, it has been hypothesized that increasing global soil organic matter stocks by 4 per 1000 (or $0.4 \%$ ) per year in agricultural land can offset $30 \%$ of global greenhouse emission [4].

The agricultural and industrial revolutions, combined with unsustainable farming practices, have significantly affected global soil health. This is mainly a consequence of the type of fertilizer used in crop production. Earlier practices of using manure and compost replenished the soil organic matter (SOM) on a regular basis. However, the use of petroleum-derived chemical fertilizers is detrimental to SOM as they enhance accumulation of salt and reduce microbial diversity. Fertilizers derived from the Haber-Bosch process contribute to more than $1 \%$ of total global $\mathrm{CO}_{2}$ emissions $[10,11]$. Soil health has further declined with gradual acidification of arable lands, negatively affecting crop yields throughout the world. While the use of compost and manure to enhance and maintain SOM is an option, it presents limitations due to accumulation of heavy metals, increased pathogen pressure, and leaching of excess nutrients into waterways leading to eutrophication.

There is a long history of enriching soils with recalcitrant carbon practiced by indigenous farmers in different parts of the world. Black-earth-like anthropogenic soils known as 'Terra Preta' have been discovered in several regions of South America and Japan. These dark soils were amended with charcoal-like substances, generally referred to as biochar (BC), which conferred enhanced fertility to the soil $[12,13]$. Chemical analysis revealed that the BC-treated areas contained 70 -times more carbon than the surrounding soils, demonstrating its long half-life [14]. The enhanced fertility of these soils most likely resulted from increased SOM, higher $\mathrm{pH}$, higher water holding capacity, and high nutrient holding capacity [14-16]. Due to the potential advantages of 'Terra Preta,' several global efforts are afoot to recreate such soils. Biochar represents an organic soil amendment that improves soil quality for agricultural production [17].

This review discusses and summarizes the various impacts biochar has on soil parameters and crop productivity. The discussion concludes with a summary of some of the challenges that need to be addressed for widespread use of biochar in agriculture.

\section{Biochar and Soil}

\subsection{Biochar}

Biochar $(\mathrm{BC})$ is a carbon (C)-rich, porous material produced during the process of pyrolysis, which involves thermochemical decomposition of organic matter in an oxygen limited environment. Any feedstock, such as forest residue, agricultural byproducts and waste biomass can be converted into liquid fuels, gasses, and BC. The properties and yields of BC are highly variable depending on the rate of pyrolysis (fast/slow), feedstock, pyrolysis temperature, and retention time. Generally, slow pyrolysis with a heating rate of $5-20^{\circ} \mathrm{C}$ per minute with higher residence time results in higher $\mathrm{BC}$ 
yield $[18,19]$. Fast pyrolysis with higher heating rate $\left(>100^{\circ} \mathrm{C} / \mathrm{min}\right)$ and lower residence time results in higher yield of liquid fuel and reduced BC output [20]. Due to the complex nature of pyrolysis and diversity of feedstock, the final chemical and physical properties of $\mathrm{BC}$ vary. For example, a recent meta-analysis concluded that $\mathrm{BC}$ produced at higher temperature $\left(600^{\circ} \mathrm{C}-699^{\circ} \mathrm{C}\right)$ had a higher $\mathrm{pH}$ $\sim 9$ compared to $\mathrm{BC}$ produced at lower temperatures $\left(300^{\circ} \mathrm{C}-399^{\circ} \mathrm{C}\right)$ with $\mathrm{pH} \sim 5$ [21]. This observation was supported by another recent meta-analysis [22]. The higher reaction temperatures reduce the amount of aliphatic carbons, oxygenated functional groups, cation exchange capacity (CEC), and total content of $\mathrm{N}, \mathrm{H}$, and $\mathrm{O}$. However, higher temperature of production resulted in increased $\mathrm{pH}$, amount of $C$ fixed, total ash content, total $C$, and surface area of BC $[21,23,24]$. Ultimately the bulk property and surface characteristics of any $\mathrm{BC}$ is determined by the feedstock source along with the pyrolysis parameters $[19,25]$. There remains a critical need to understand the characteristics of BCs produced from different feedstock, pyrolysis parameters, and the resulting relative impact on soil. In the following sections, recent research on $\mathrm{BCs}$ has been collated and the effects of various $\mathrm{BC}$ regimens on soil physical properties, soil-water relations, soil organic matter, microbial activity, soil tilth and nutrient status, $\mathrm{pH}$, crop productivity, biotic and abiotic stresses have been discussed.

\subsection{Impact of Biochar on Soil}

\subsubsection{Physical Properties}

Physical properties of soil, such as bulk density, porosity, and water retention are important variables that impact plant growth and development. Human intervention in agricultural practices causes soil compaction, which is one of the key factors affecting plant growth [26]. Soil compaction above $1.7 \mathrm{~g} \mathrm{~cm}^{-3}$ results in restricted root growth and limits access to water and nutrients [27]. As a consequence, yields of many crops such as soybean and corn have been shown to be negatively impacted [28,29]. Amending soils with biochar increases soil porosity while decreasing soil bulk density, which aids in transport of water, nutrients, and gases. These alterations encourage root formation and increased microbial respiration [22].

A meta-analysis reported that the addition of BC to soil reduced bulk density of the soil by an average of $7.6 \%$ and increased its water holding capacity and porosity by $15.1 \%$ and $8.4 \%$, respectively [30]. Similar results were reported in another meta-analysis where the average bulk density was decreased by 12\% [31]. Fifteen of the 17 studies conducted in 2019 reported that biochar effectively reduced soil bulk density and increased porosity and available water content (Table 1). However, there were two studies that reported either no effect on bulk density after addition of BC [32] or an insignificant decrease [33]. It was also observed that larger average BC particle size was more effective in reducing bulk density of sandy loam soil than sandy soil [34]. In case of sandy soil, bulk density significantly decreased and water holding capacity was significantly increased with addition of BC with small particle size [34]. A majority of the recent studies used biochar produced from agricultural residue and woody residue. Generally, a positive effect on the physical properties of soil was reported (Table 1).

Table 1. Selected studies summarizing the impact of biochar on the physical properties of soil. 


\begin{tabular}{|c|c|c|c|c|c|c|c|c|}
\hline $\begin{array}{l}\text { Exp. } \\
\text { type }\end{array}$ & $\begin{array}{c}\text { BC } \\
\text { feedstock }\end{array}$ & $\begin{array}{c}\text { Pyrolysis } \\
\text { temperature } \\
\left({ }^{\circ} \mathrm{C}\right)\end{array}$ & $\begin{array}{l}\text { Soil } \\
\text { type }\end{array}$ & $\begin{array}{c}\text { Bulk } \\
\text { density }\end{array}$ & $\begin{array}{c}\text { Available } \\
\text { water } \\
\text { content }\end{array}$ & $\begin{array}{c}\text { Total } \\
\text { porosity }\end{array}$ & Country & $\begin{array}{l}= \\
0 \\
0 \\
0 \\
0 \\
0 \\
0 \\
0 \\
0\end{array}$ \\
\hline \multirow{2}{*}{ Lab } & \multirow{2}{*}{$\begin{array}{l}\text { Agricultural } \\
\text { residues }\end{array}$} & \multirow{2}{*}{450} & Loamy & $\begin{array}{c}\text { Slightly } \\
\text { decreased }\end{array}$ & Increased & Increased & \multirow[t]{2}{*}{ Brazil } & \multirow{2}{*}{ [33] } \\
\hline & & & Sandy & $\begin{array}{c}\text { Slightly } \\
\text { decreased }\end{array}$ & Increased & Increased & & \\
\hline \multirow[t]{2}{*}{ Lab } & \multirow{2}{*}{$\begin{array}{l}\text { Woody } \\
\text { residues }\end{array}$} & \multirow[t]{2}{*}{620} & $\begin{array}{l}\text { Sandy } \\
\text { loam }\end{array}$ & Decreased & Increased & \multirow[t]{2}{*}{ N/A } & \multirow[t]{2}{*}{ Portugal } & \multirow[t]{2}{*}{ [34] } \\
\hline & & & Sandy & Decreased & Increased & & & \\
\hline Field & N/A & N/A & N/A & Decreased & Increased & Increased & Pakistan & [35] \\
\hline Field & $\begin{array}{l}\text { Sewage } \\
\text { sludge }\end{array}$ & $700-850$ & $\begin{array}{l}\text { Loamy } \\
\text { sand }\end{array}$ & Decreased & N/A & N/A & China & [36] \\
\hline \multirow{2}{*}{ Lab } & \multirow{2}{*}{$\begin{array}{l}\text { Agricultural } \\
\text { residues }\end{array}$} & \multirow{2}{*}{450} & $\begin{array}{l}\text { Sandy } \\
\text { loam }\end{array}$ & Decreased & No effect & Increased & \multirow{2}{*}{ Brazil } & \multirow{2}{*}{ [37] } \\
\hline & & & $\begin{array}{l}\text { Clay } \\
\text { loam }\end{array}$ & Decreased & Increased & Increased & & \\
\hline Field & $\begin{array}{c}\text { Agricultural } \\
\text { residues }\end{array}$ & $200-600$ & $\begin{array}{l}\text { Loam } \\
\text { sand }\end{array}$ & Decreased & N/A & Increased & Iran & [38] \\
\hline Field & $\begin{array}{l}\text { Agricultural } \\
\text { residues }\end{array}$ & 360 & $\begin{array}{l}\text { Sandy } \\
\text { loam }\end{array}$ & Decreased & N/A & Increased & China & [39] \\
\hline Lab & $\begin{array}{l}\text { Agricultural } \\
\text { residues }\end{array}$ & $300 \& 700$ & Desert & Decreased & Increased & Increased & China & [40] \\
\hline Field & $\begin{array}{l}\text { Woody } \\
\text { residues }\end{array}$ & N/A & N/A & Decreased & Increased & Increased & Kenya & [41] \\
\hline $\mathrm{Lab}$ & $\begin{array}{l}\text { Agricultural } \\
\text { residues }\end{array}$ & $350-650$ & Sandy & Decreased & Increased & N/A & UAE & [42] \\
\hline $\mathrm{Lab}$ & $\begin{array}{l}\text { Woody } \\
\text { residues }\end{array}$ & 350 & $\begin{array}{l}\text { Sandy } \\
\text { loam }\end{array}$ & Decreased & Increased & Increased & Brazil & [43] \\
\hline Field & $\begin{array}{l}\text { Woody } \\
\text { residues }\end{array}$ & 500 & $\begin{array}{l}\text { Silt } \\
\text { loam }\end{array}$ & Decreased & Increased & Increased & USA & [44] \\
\hline Field & $\begin{array}{l}\text { Agricultural } \\
\text { residues }\end{array}$ & $550-600$ & $\begin{array}{l}\text { Clay } \\
\text { loam }\end{array}$ & Decreased & N/A & Increased & China & [45] \\
\hline Yard & $\begin{array}{c}\text { Agricultural } \\
\text { residues }\end{array}$ & $400-450$ & $\begin{array}{c}\text { Planoso } \\
1\end{array}$ & Decreased & Increased & Increased & China & [46] \\
\hline Field & $\begin{array}{l}\text { Agricultural } \\
\text { residues }\end{array}$ & 550 & $\begin{array}{l}\text { Haplic } \\
\text { Luvisol }\end{array}$ & Decreased & Increased & Increased & Slovakia & [47] \\
\hline $\mathrm{Lab}$ & $\begin{array}{l}\text { Forest } \\
\text { residue }\end{array}$ & 450 & $\begin{array}{l}\text { Desert } \\
\text { sandy }\end{array}$ & Decreased & Increased & Increased & UAE & [48] \\
\hline Field & $\begin{array}{l}\text { Agricultural } \\
\text { residues }\end{array}$ & 550 & $\begin{array}{l}\text { Sandy } \\
\text { clay } \\
\text { loam }\end{array}$ & $\begin{array}{c}\text { No } \\
\text { difference }\end{array}$ & Increased & Increased & Ghana & [32] \\
\hline
\end{tabular}




\begin{tabular}{|c|c|c|c|c|c|c|c|c|}
\hline Field & $\begin{array}{c}\text { Woody } \\
\text { residues }\end{array}$ & 580 & Luvisol & Decreased & Increased & Increased & Nigeria & [49] \\
\hline
\end{tabular}

A most recent meta-analysis showed an average increase in soil porosity by $6.27 \%$, decrease in bulk density by $7.47 \%$, and increase in water holding capacity by $9.82 \%$ [50]. However, biochar derived from softwood and walnut shell did not affect soil porosity or water retention over a period of six years in silty clay soil. It was suggested the effect on soil porosity and water retention was temporary until the pores of biochar were occluded with clay or soil organic matter (SOM) [51]. Woody biomass derived-biochar was shown to have no effect on soil porosity or water retention after four years of amendment [52].

Comparably, in the case of soil bulk density, a majority of the studies reported a decrease after $B C$ amendment $[30,31,50]$. There were also a few reports where no significant decrease in bulk density was observed [53-56]. A majority of the data from previous meta-analyses and reports indicate that addition of $\mathrm{BC}$ to a coarse, textured soil had a larger positive impact on soil physical properties compared to clay textured soil $[30,31,50,57,58]$.

Biochar produced from wheat straw $\left(550^{\circ} \mathrm{C}-600^{\circ} \mathrm{C}\right)$ incorporated with clay loamy soil improved its physical properties and enhanced the yield of wheat when irrigated with saline water [45]. The biochar amendment decreased soil bulk density by $5.5 \%-11.6 \%$ and increased porosity by $35.4 \%$ $49.5 \%$. The biochar amendment also seemed to mitigate soil sodicity and also increased total NPK availability in mixed soil layer. This resulted in the improvement of wheat yield by $8.6 \%$ and $8.4 \%$ at the BC application rates of 10 and $20 \mathrm{t} / \mathrm{ha}^{-1}$, respectively [45]. However, at the application rate of 30 $\mathrm{t} / \mathrm{ha}^{-1}$ the improvement in yield was the lowest $(2.2 \%)$ probably due to high salinity and immobilization of $\mathrm{N}$. This study suggests that for saline irrigation in clay loamy soil, the optimal application rate of $\mathrm{BC}$ produced from agricultural residue should be between 10-20 t/ha-145]. These studies imply that initial soil characteristics, along with $\mathrm{BC}$ application rate and type, determine the final changes in the physical properties of the soil.

\subsection{Soil-Water relations}

Accessible fresh water supplies are becoming increasingly limited, and 70\% of available fresh water supports crop irrigation [59]. Although biochar holds promise for improved hydrological functions, there are differing schools of thought regarding the role of $\mathrm{BC}$ in improving the long- term water holding capacity of soil [60]. BC amendment has been reported to increase rainfall absorption and soil water-holding capacity, particularly in non-irrigated production regions [61-63]. However, the preexisting physical and biochemical characteristics of the soil and the wide array of $\mathrm{BC}$ production parameters (feedstock inputs, pyrolysis temperatures, application methods, and geographical variables) ultimately determine the $\mathrm{BC}^{\prime} \mathrm{s}$ impact on water holding capacity. In order to probe the influence of $B C$ on water dynamics, initial experiments were performed with soil columns in greenhouses with addition of farm or potting soils. Field studies are now becoming prevalent in peer reviewed literature, particularly within the last 10 years.

The identification of key features that contribute to improved water retention could lead to an expanded role for $\mathrm{BC}$ in crop production. Overall, it was determined that feedstock selection and pyrolysis temperature, the most predictive variables impacting water status, impact BC surface chemistry and porosity, the latter of which is a major contributor to the water holding capacity of $\mathrm{BC}$ 
$[64,65]$. Pore saturation is highly dependent on BC surface chemistry, which is affected by pyrolysis temperature. An increase in pyrolysis temperature volatilizes organic elements and thermally cracks the biomass, thereby rendering hydrophobic compounds more hydrophilic and increasing overall BC porosity [66]. Conversely, BCs produced via low temperature pyrolysis exhibit negative capillary pressure, inhibiting the hydration of the pore space [67].

Comparative analysis of Fourier transform infrared (FTIR) spectroscopy data collected from nine different feedstocks pyrolyzed at $250^{\circ} \mathrm{C}, 500^{\circ} \mathrm{C}$, and $700^{\circ} \mathrm{C}$ revealed the relationship between $\mathrm{BC}$ surface chemistry and hydrophobicity [68]. The spectrometer data indicated that the functional group $\mathrm{C}=\mathrm{O}$ in carboxylic acid was present only in the $\mathrm{BC}$ obtained from pyrolysis at $250^{\circ} \mathrm{C}$, making it hydrophobic. $\mathrm{BC}$ produced at $500^{\circ} \mathrm{C}$ and $700^{\circ} \mathrm{C}$ were deemed more appropriate for improving soil water status. A significant correlation was identified between low pyrolysis temperature $\left(<300^{\circ} \mathrm{C}\right)$ and surface functional groups (specifically acidic moieties), and increased hydrophobicity contributing to low water retention was reported [64,69]. Other factors, including cation exchange capacity, play a role along with the variables of surface groups and porosity in determining the hydrophobic properties for each specific BC [70].

Considerable variation in total pore volumes was reported in $\mathrm{BC}$ s produced at $400^{\circ} \mathrm{C}, 600^{\circ} \mathrm{C}$ and $800^{\circ} \mathrm{C}$ from various feedstocks. Wood-based BC possessed a comparatively higher range of micropores $(5-30 \mu \mathrm{m})$ and, although the number of micropores decreased with increasing pyrolysis temperatures, this $\mathrm{BC}$ still retained relatively large pore volumes overall due to pyrogenic micropores. In contrast, pore volumes of $\mathrm{BC}$ derived from poultry manure and agricultural wastewater sludge were smaller, indicating that these feedstocks may not be suitable for improving water retention in amended soils [71]. While BC amendment imparts large increases in porosity, permeability, and moisture retention in clay soils, these affects are diminished in silt-loam soils [72,73]. Particle size of $\mathrm{BC}$ had clear impact on soil bulk density, with a linear decrease in bulk density of sandy soil observed when large-particle-containing hardwood $\mathrm{BC}\left(620^{\circ} \mathrm{C}\right)$ was used. Smaller BC particles increased water holding capacity compared to larger BC particles [34], possibly due to increased microporosity resulting from higher pyrolysis temperatures. Despite this, addition of $\mathrm{BC}$ at $25 \mathrm{Mg} \mathrm{ha}^{-1}$ to sandy soils did not result in increased water retention. In a study with Miscanthus giganteus residue-derived BC $\left(450^{\circ} \mathrm{C}\right)$, the increased porosity of larger $\mathrm{BC}$ particles proved beneficial for soil water retention, while smaller BC particles under $0.15 \mathrm{~mm}$ retained water too well, thereby strongly reducing its bioavailability [33].

BC was reported to increase the water holding capacity in coarse and medium textured soils by an average of $51 \%$ and $13 \%$, respectively [74]. This was attributed to a higher abundance of soil micropores resulting from the intrinsic micro-porosity of BC. However, a reduction in water holding capacity was reported in fine-textured soils, possibly due to the overall decrease in micropores or occlusion of existing pores. Field studies of high-porosity BCs derived from softwood $\left(600^{\circ} \mathrm{C}-700^{\circ} \mathrm{C}\right)$ and walnut shell $\left(900^{\circ} \mathrm{C}\right)$ reported temporary improvement of water holding capacity; however, no long-term improvement was seen in BC-amended silty-clay-loam soils subjected to a corn-tomato rotation with conventional or organic production regimes [51]. Plant-available water in fine-textured soils could be enhanced through management or manipulation of hydrophobic properties of BC, thereby improving BC-soil interactions [74]. For example, it has been reported that grapevine feedstocks subjected to low pyrolysis temperatures $\left(\sim 400^{\circ} \mathrm{C}\right)$ yield $\mathrm{BC}$ with a $23 \%$ higher available 
water content in clay soils [75].

\subsection{Soil tilth and nutrient status}

Defining management approaches to increase the productivity of agricultural soils remains a priority as food demand increases and arable farmland decreases [76]. As a mineral-rich organic material, BC can be incorporated into agricultural soils, potentially serving as a slow-releasing fertilizer, positively affecting soil tilth and enhancing the nutrient status of agricultural soils [77-79]. The basis for this potential use lies in the unique porosity of $\mathrm{BC}$, its facilitation of chemical and physical interactions between nutrients and the carbon material, and its strong intrinsic sorption properties. Due to the large surface area, porous microstructures, and negative surface charge, $B C$ enhances nutrient retention in the soil. Furthermore, the nutrient retention properties of BC may significantly reduce irrigation or rainfall-induced leaching of water-soluble minerals [62,80]. The slow desorption of the BC-sequestered nutrient elements may supply a steady rate of nutrient delivery, thereby alleviating the need for excessive fertilizer use. Together, these agronomic benefits to soil health may also mitigate freshwater eutrophication that results from fertilizer runoff, prevent pesticide contamination, and reduce the risk of environmental damage [81-83].

While composition varies based on feedstock and pyrolysis parameters, a universal characteristic of $B C$ is that it is carbon-dense, which facilitates retention of necessary plant nutrients such as $\mathrm{N}, \mathrm{P}, \mathrm{K}, \mathrm{Mg}, \mathrm{Fe}$ and $\mathrm{Ca}$ [84-87]. Depending on the soil status and existing nutrient deficiencies, BCs can be custom-manufactured to replenish depleted nutrients. It has been demonstrated that $\mathrm{BC}$ derived from different feedstocks possess variable amounts of beneficial plant nutrients $[43,62,87-90]$. The general characteristics of three major BC feedstock sources are as follows:

- Organic waste feedstocks, such as animal manure and sewage sludge-derived BC, are rich in potassium and phosphorus, low in C levels, and low in surface area; additionally, eggshellderived $B C$ is elevated in calcium levels

- Wood-based BC is high in organic matter and surface area, while low in CEC and N, P, and K levels

- Crop residue-derived BC properties reside somewhere in between those of the two previous categories, with specific crops producing $\mathrm{BC}$ with different properties (e.g., wheat and rice $\mathrm{BC}$ is high in silicon content; soybean $\mathrm{BC}$ is high in $\mathrm{N}$ )

These feedstocks can be blended in appropriate ratios to produce BCs with desired nutrient and/or mineral profiles. Further modifications, including alteration of pyrolysis parameters, physical alterations, chemical modifications, and BC-mediated composting have been discussed to aid in the customization of $\mathrm{BC}$ to ameliorate detrimental soil aspects [87].

Soil $\mathrm{pH}$ and abundance/availability of important plant nutrients such as phosphorus $(\mathrm{P})$ and nitrogen $(\mathrm{N})$ are positively affected in $\mathrm{BC}$-amended soils. Limiting the pyrolysis temperatures to less than $700^{\circ} \mathrm{C}$ enhances the levels of $\mathrm{P}$ and $\mathrm{N}$ in $\mathrm{BC}$, both of which can be lost at higher temperatures due to volatilization and transformation of $\mathrm{NH} 4+$ to heterocyclic- $\mathrm{N}$ [88]. Woodderived $\mathrm{BC}\left(450^{\circ} \mathrm{C}-550^{\circ} \mathrm{C}\right)$ applied at $20 \mathrm{t} / \mathrm{ha}^{-1}$ significantly improved the bioavailability of $\mathrm{P}$ in sandy soils, an effect that was primarily attributed to perturbation of abiotic processes (adsorption/desorption of $\mathrm{P}$, altered redox potentials, development of organo-mineral aggregations) [91]. BC nitrogen levels are correlated closely with the original source of the char; feedstocks high 
protein biomass, such as grasses, generate BCs with higher $\mathrm{N}$ levels ( $10 \%$ by weight), while woodderived $\mathrm{BC}$ s tend to be N-poor ( $1 \%$ by weight) [88]. While several individual studies show that wheat $\mathrm{BC}\left(450^{\circ} \mathrm{C}\right)$ applications increased total soil $\mathrm{N}$ [92], other studies found significant decreases of soil $\mathrm{NH}_{4}{ }^{+}$and $\mathrm{NO}_{3}{ }^{-}$following $\mathrm{BC}$ addition. The latter outcome was likely due to inherent recalcitrance of the small amount of extractable inorganic $\mathrm{N}$ and organic $\mathrm{N}$ present. In the studies reporting increased $\mathrm{N}$, this increase could be attributed to heightened abundance of recruited microorganisms, which assist in the degradation of soil organic nitrogen [93].

In addition to improving mineral nutrient retention, $\mathrm{BC}$ has a role in amelioration of soil erosion and improvement of overall soil structure [94,95]. A study utilizing hardwood $\left(600^{\circ} \mathrm{C}\right) \mathrm{BC}$ at 15 and $30 \mathrm{t} / \mathrm{ha}^{-1}$ concentrations to amend clay-rich soils in incubation containers demonstrated improved soil aggregate structure and soil stabilization [96]. This is likely due to interaction of carboxylic and phenolic functional groups on the BC surface, resulting in formation of cation bridges and consequent $\mathrm{BC}$-mineral complexes [97]. For example, micro-aggregates observed to form upon incorporation of hardwood-derived $\mathrm{BC}\left(700^{\circ} \mathrm{C}\right)$ into soil with application rates of $2.5 \%$ or $5 \%$ correlated with $50 \%-64 \%$ decrease in soil loss, respectively [98]. An additional study with oak wood-derived $\mathrm{BC}$ applied at a rate of $10 \mathrm{Mg} / \mathrm{ha}^{-1}$ provided further evidence for the stabilizing effects of BC, with significant decreases in soil loss of almost $20 \%$ observed in a simulated rainfall experiment. In addition to improving soil retention, $\mathrm{BC}$ appeared to reduce the impact force from rainfall, thereby facilitating reduction of particle detachment [99].

\subsection{Soil acidification}

The expanding global incidence of soil acidification is concerning, with acidic soils $(\mathrm{pH}<5.5)$ currently accounting for approximately $50 \%$ of arable land $[100,101]$. The excessively low $\mathrm{pH}$ of acidic soil results in reduced productivity and decreased crop fertility. The main causes of soil acidification include the use of ammonia-based fertilizers and low nitrogen use efficiency. In soil, ammonia fertilizers are converted to nitrates and hydrogen ions. The hydrogen ions that are left over following uptake of nitrates by crops or after nitrate leaching increase the soil acidity [102]. Removal of crop residue, also accelerate soil acidification. Excessive reduction of $\mathrm{pH}$ leads to increased solubility of soil-bound aluminum; thus, soil acidification generally leads to aluminum (Al) toxicity [101]. Aluminum toxicity, in turn, leads to deficiencies in phosphorus, calcium, magnesium, and potassium cations and contributes to impaired root growth.

Current strategies to alleviate soil acidification include liming, application of crop residue, and use of industrial products; however, these methods have several disadvantages. Liming material, for example, elicits a disproportionately strong effect on top surface soils in comparison with lower layers. This method is also costly, due to the high transportation costs of liming material [102,103]. Application of industrial products can lead to heavy metal toxicity [104]. Similarly, excessive application of organic material may lead to both heavy metal accumulation and eutrophication, the latter resulting from augmented concentrations of nitrogen and phosphorus [22,105]. Hence, biochar, which is naturally alkaline, is a potential solution to the problem of soil acidity.

Various studies have validated the effectiveness of BC in reducing soil acidity [106-108], and a linear correlation of biochar alkalinity with the resulting soil $\mathrm{pH}$ has been established [101]. Furthermore, it has been demonstrated that increased $\mathrm{pH}$ buffering capacity of BC-amended soils is due to a BC-derived increase in cation exchange capacity [111]. The carbonates and oxides of cations 
such as $\mathrm{Ca}, \mathrm{K}, \mathrm{Mg}$, $\mathrm{Na}$ and $\mathrm{Si}$ formed during pyrolysis are known to react with dissolved $\mathrm{Al}$ and hydrogen ions in soil, leading to increased soil $\mathrm{pH}$ and decreased $\mathrm{Al}$ uptake by the plants [112]. Previous meta-analyses and individual studies have concluded that, in imparting increased buffering capacity, BC amendment can increase the soil $\mathrm{pH}$ by $>2.0$ units [109]. Not surprisingly, the original feedstock material plays a key role in determining the final $\mathrm{pH}$ of $\mathrm{BC}$. For example, BC generated from manure has higher alkalinity, $\mathrm{pH}$ buffering capacity, and propensity for alleviation of $\mathrm{Al}$ toxicity, compared to crop residue-derived BC. Thus, the former would be more suitable for extremely acidic soils [110]. Soils exhibiting Al toxicity could be reclaimed via BC amendment, the ash content of which would precipitate $\mathrm{Al}_{3}{ }^{+}$to less toxic $\mathrm{Al}(\mathrm{OH})_{3}$ and $\mathrm{Al}(\mathrm{OH})_{4}$ [113]. Furthermore, carboxyl and other organic functional groups on the $\mathrm{BC}$ surface would provide additional sites for $\mathrm{Al}_{3}{ }^{+}$binding [113]. Functional groups such as $\mathrm{COO}^{-}$and $\mathrm{O}^{-}$also contribute to alkalinity of biochar through reaction with free $\mathrm{H}^{+}$ions $[23,114]$.

In soil, $\mathrm{H}+$ is produced through aerobic conversion of ammonia to nitrate. Experimental results have demonstrated that $\mathrm{BC}$ amendment leads to decreased soil nitrification through adsorption of $\mathrm{NH}_{3}$ and $\mathrm{NH}_{4}$ onto the $\mathrm{BC}$ surface. Soil amendment with wheat straw-derived $\mathrm{BC}\left(500^{\circ} \mathrm{C}\right)$ led to reduced nitrification in cadmium contaminated Ferralsol soil by decreasing soil acidity (Table 2) [115]. Similarly, amendment with pig manure-derived $\mathrm{BC}\left(300^{\circ} \mathrm{C}\right)$ resulted in decreased soil acidification and increased cation exchange capacity [116,117], and crop residue-derived $B C\left(500^{\circ} \mathrm{C}\right)$ lead to improved rice growth, yield, and soil nutrient availability in acidified soil [118]. Collectively, information from the literature has established that carbon content, nutrient availability and alkalinity is highest when BC is generated from manure feedstock, intermediate when generated from crop residue feedstock, lowest when generated from woody plants-based feedstock (Table 2). Finally, biochar produced at higher temperature has higher $\mathrm{pH}$ and might be more suitable for countering soil acidity.

Table 2. Selected recent studies documenting the impact of biochar on acidified soils.

\begin{tabular}{|c|c|c|c|c|c|c|}
\hline $\begin{array}{l}\text { Exp. } \\
\text { type }\end{array}$ & Soil type & BC feedstock & $\begin{array}{c}\text { Pyrolysis } \\
\text { temperature } \\
\left({ }^{\circ} \mathrm{C}\right)\end{array}$ & $\begin{array}{l}\text { Effect of biochar } \\
\text { amendment }\end{array}$ & Country & $\begin{array}{l}\sqrt{0} \\
0 \\
0 \\
0 \\
0 \\
0 \\
0 \\
0\end{array}$ \\
\hline $\mathrm{Lab}$ & Ultisols & Crop residue & 400 & $\begin{array}{l}\text { Decreased soil } \mathrm{pH} \text { and } \\
\text { the increased in } \\
\text { exchangeable acidity } \\
\text { and pH buffering } \\
\text { capacity }\end{array}$ & China & [101] \\
\hline $\mathrm{Lab}$ & Ferrosol & Crop residue & 450 & $\begin{array}{c}\text { Inhibited nitrification } \\
\text { and acidification of } \mathrm{Cd} \\
\text { contaminated soils. }\end{array}$ & China & [115] \\
\hline $\mathrm{Lab}$ & Sandy & $\begin{array}{l}\text { Pig manure } \\
\text { and poultry } \\
\text { litter }\end{array}$ & 300 & $\begin{array}{l}\text { Decreased soil } \\
\text { acidification and } \\
\text { increased cation } \\
\text { exchange capacity }\end{array}$ & Poland & {$[116]$} \\
\hline
\end{tabular}




\begin{tabular}{|c|c|c|c|c|c|c|}
\hline \multirow[b]{2}{*}{$\mathrm{Lab}$} & Ultisols & \multirow[b]{2}{*}{ Crop residue } & \multirow[b]{2}{*}{400} & \multirow{2}{*}{$\begin{array}{c}\text { Increased soil pH } \\
\text { buffering capacity and } \\
\text { increased the resistance } \\
\text { of soils to re- } \\
\text { acidification. }\end{array}$} & \multirow[b]{2}{*}{ China } & \multirow[b]{2}{*}{119} \\
\hline & Oxisol & & & & & \\
\hline $\mathrm{Lab}$ & Ultisols & Crop residue & 400 & $\begin{array}{c}\text { Increased soil } \mathrm{pH} \text {, } \\
\text { neutralized soil acidity, } \\
\text { increased soil } \mathrm{pH} \\
\text { buffering capacity and } \\
\text { increased resistance of } \\
\text { soils to re-acidification }\end{array}$ & China & [120] \\
\hline $\mathrm{Lab}$ & $\begin{array}{c}\text { Not } \\
\text { Reported }\end{array}$ & Crop residue & 500 & $\begin{array}{l}\text { Biochar significantly } \\
\text { promoted rice growth } \\
\text { and the yield increased } \\
\text { in acidified soil. }\end{array}$ & China & {$[118]$} \\
\hline $\mathrm{Lab}$ & Oxisols & Crop residue & N/A & $\begin{array}{l}\text { Alleviated soil } \\
\text { acidification }\end{array}$ & China & [121] \\
\hline $\mathrm{Lab}$ & $\begin{array}{l}\text { Loamy } \\
\text { sand }\end{array}$ & $\begin{array}{l}\text { Sewage } \\
\text { sludge }\end{array}$ & 300 & $\begin{array}{l}\text { Reduced soil } \\
\text { acidification }\end{array}$ & Poland & [122] \\
\hline
\end{tabular}

\section{Biochemical properties}

\subsection{Soil organic matter (SOM)}

Soil organic matter (SOM) comprises the total organic carbon in a soil and is the main determinant of overall soil fertility. SOM components consist of plant residue, animal waste, microbial populations, and active and stable organic matter in soil. SOM contributes to soil fertility by serving as a nutrient source for crops and microbes, causes soil aggregation, and improves water retention and nutrient exchange. It also helps to reduce soil compaction and surface crusting. It has been reported that the impact of biochar on SOM depends on the following variables [123-125]:

1. Type of biomass used for production of $\mathrm{BC}$

2. Pyrolysis temperature

3. Pre-existing SOM levels in the soil

Amending soils with biochar often results in alterations in C cycling and mineralization, and this effect is known as 'priming'. Previous studies have reported both positive and negative effects of priming. Grass-derived BC produced at lower temperatures $\left(250^{\circ} \mathrm{C}\right.$ and $\left.400^{\circ} \mathrm{C}\right)$ resulted in positive priming resulting in increased $\mathrm{C}$ mineralization. However, $\mathrm{BC}$ produced at higher temperatures $\left(525^{\circ} \mathrm{C}\right.$ and $\left.600^{\circ} \mathrm{C}\right)$ from hardwood resulted in negative priming [124]. It was hypothesized that negative priming resulted from the organic matter binding to the biochar and thereby becoming unavailable to microbial and enzymatic action.

Analogous results were observed in a study that showed that crop residue-derived biochar produced at lower temperature $\left(300^{\circ} \mathrm{C}-550^{\circ} \mathrm{C}\right)$ generally resulted in positive priming when applied to arable and fallow soils; however, in the case of grassland soils the effect was negative [123]. In another study, which aimed to analyze the short-term effect of biochar on SOM, BC produced from 
woody feedstocks at lower temperatures $\left(350^{\circ} \mathrm{C}\right)$ had greater positive priming during 0-13 days of biochar application both in low and high $\mathrm{pH}$ clay loam soil [126]. The extent of positive priming was reduced for low and high $\mathrm{pH}$ clay loam soil when $\mathrm{BC}$ produced at higher temperature $\left(700^{\circ} \mathrm{C}\right)$ was used. The addition of fresh labile substrate, such as rye grass, to $\mathrm{BC}$ produced at both high and low temperatures further increased priming and mineralization [126]. If the goal is to sequester carbon, rapid mineralization caused in conjunction with low temperature-derived $\mathrm{BC}$ results in carbon loss, necessitating BC reapplication. Application of high temperature-derived BC can also be used to reduce the priming effect and aide in carbon sequestration.

Addition of $3 \%(\mathrm{w} / \mathrm{w}) \mathrm{BC}$ prepared from forest residues at $550^{\circ} \mathrm{C}$ has been reported to delay the decomposition of SOM and reduce $\mathrm{N}$ mineralization when added to acidic red loam soil [127]. However, some studies did not find BC to contribute to SOM decomposition [128,129]. A reduction in priming, and a $16 \%$ reduction of SOM decomposition, was reported when crop residue-derived BC pyrolyzed via gasification at $1200^{\circ} \mathrm{C}$ was added to sandy loam soil [130]. The reduction may be due to a shift in the preference of the microbial community for biochar as a $C$ source [131]. There have been various studies in which $\mathrm{BC}$ produced at lower temperature ranging from $450^{\circ} \mathrm{C}-550^{\circ} \mathrm{C}$ stimulated positive priming when added to sandy loam (Table 3). Overall, BC promoted increases in $\mathrm{C}$ sequestration, organic carbon retention, $\mathrm{SOM}$, mineralization, phosphorous and potassium content, and plant biomass [132-135]. Conversely, one study reported a decrease in soil microbial biomass and SOM mineralization when crop residue-derived $\mathrm{BC}\left(450^{\circ} \mathrm{C}\right)$ was applied to sandy loam soil [136].

Table 3. Selected recent studies summarizing the effect of biochar on soil organic matter (SOM).

\begin{tabular}{|c|c|c|c|c|c|c|}
\hline $\begin{array}{l}\text { Exp. } \\
\text { type }\end{array}$ & Soil type & BC feedstock & $\begin{array}{c}\text { Pyrolysis } \\
\text { temperature } \\
\left({ }^{\circ} \mathrm{C}\right)\end{array}$ & $\begin{array}{l}\text { Effect of biochar } \\
\text { amendment }\end{array}$ & Country & 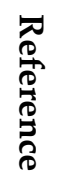 \\
\hline $\mathrm{Lab}$ & $\begin{array}{l}\text { Acidic red } \\
\text { loam }\end{array}$ & $\begin{array}{l}\text { Forest } \\
\text { residue }\end{array}$ & 550 & $\begin{array}{l}\text { Decomposition of } \\
\text { SOC declined and } \\
\text { reduced } \\
\text { mineralization of } \\
\text { SOM }\end{array}$ & China & {$[127]$} \\
\hline Field & $\begin{array}{l}\text { Sandy } \\
\text { loam }\end{array}$ & Crop residue & $\begin{array}{l}\text { Gasification } \\
\text { at } 1200\end{array}$ & $\begin{array}{c}\text { Reduced SOM } \\
\text { degradation by } 16 \% \text {. }\end{array}$ & Italy & [130] \\
\hline $\mathrm{Lab}$ & $\begin{array}{l}\text { Podzol } \\
\text { Antric }\end{array}$ & $\begin{array}{l}\text { Woody } \\
\text { biomass }\end{array}$ & 550 & $\begin{array}{c}\text { Increased the SOM } \\
\text { mineralization. }\end{array}$ & Russia & [137] \\
\hline \multirow{2}{*}{ Field } & \multirow{2}{*}{ Sandy } & \multirow{2}{*}{ Crop residue } & 350 & $\begin{array}{c}\text { Increased soil organic } \\
\text { matter and } \mathrm{N}\end{array}$ & \multirow{2}{*}{ Tunisia } & \multirow{2}{*}{ [138] } \\
\hline & & & 450 & $\begin{array}{c}\text { Decreased organic } \\
\text { matter and } \mathrm{N} \text { content }\end{array}$ & & \\
\hline Field & $\mathrm{N} / \mathrm{A}$ & $\begin{array}{l}\text { Sewage } \\
\text { sludge } \\
\text { biochar }\end{array}$ & Not Reported & SOM are increased & Brazil & {$[132]$} \\
\hline
\end{tabular}




\begin{tabular}{|c|c|c|c|c|c|c|}
\hline Field & $\begin{array}{c}\text { Plaggic } \\
\text { Anthrosols }\end{array}$ & Crop residue & 350 & Positive priming & Russia & [133] \\
\hline Field & Silt loams & $\begin{array}{l}\text { Woody } \\
\text { biomass }\end{array}$ & 900 & $\begin{array}{c}\text { Increased soil organic } \\
\text { matter, soil pH, } \\
\text { phosphorus, } \\
\text { potassium, sulfur, } \\
\text { and the shoot and } \\
\text { root biomass of } \\
\text { wheat. }\end{array}$ & USA & [134] \\
\hline Field & $\begin{array}{l}\text { Sandy } \\
\text { loam }\end{array}$ & Crop residue & 450 to 500 & $\begin{array}{c}\text { Decrease of } \\
\text { SOM mineralization, } \\
\text { reduce soil microbial } \\
\text { biomass }\end{array}$ & Spain & [136] \\
\hline $\mathrm{Lab}$ & $\begin{array}{l}\text { Sandy } \\
\text { loam }\end{array}$ & $\begin{array}{l}\text { Woody } \\
\text { biomass }\end{array}$ & 450 & $\begin{array}{c}\text { Increased organic } \\
\text { carbon retention } \\
\text { and promoted carbon } \\
\text { sequestration }\end{array}$ & UK & [135] \\
\hline Field & $\begin{array}{l}\text { Sandy } \\
\text { loam }\end{array}$ & Crop residue & 360 & $\begin{array}{c}\text { SOC increased after } \\
\text { biochar application } \\
\text { but did not } \\
\text { contribute to soil } \\
\text { aggregation. }\end{array}$ & China & [39] \\
\hline $\mathrm{Lab}$ & $\begin{array}{l}\text { Sandy } \\
\text { loam }\end{array}$ & Crop residue & 600 & $\begin{array}{c}\text { Significantly } \\
\text { increased SOM, } \\
\text { microbial respiration } \\
\text { and microbial } \\
\text { biomass. }\end{array}$ & Iran & [139] \\
\hline
\end{tabular}

\subsection{Microbial activity}

Considerable emphasis has been placed on the topic of microbial dynamics in agricultural systems and their role in crop productivity. The health and diversity of soil microbial populations as a function of agro-ecosystem wellbeing has diverse implications for water use efficiency, soil structure and stability, nutrient cycling, disease resistance, and eventual crop productivity [140,141]. While other organic amendments are only stable for relatively short periods in the soil environment, $\mathrm{BC}$ is more stable and remains in the soil for hundreds to thousands of years, as it is not easily degraded, and could support soil microbial communities for an extended period of time with reduced inputs [62].

The diverse and specific physiochemical characteristics of $\mathrm{BC}$ that influence soil microbial composition are increased labile carbon, $\mathrm{pH}$, surface area for colonization, and water content in amended soils. BC addition induces remodeling of the microbial diversity and community structure of the soil; however, the changes are highly variable and dependent on the individual soil properties $[142,143]$. It was reported that low pyrolysis temperature $\mathrm{BCs}\left(>350^{\circ} \mathrm{C}\right)$ harbor a greater number of organic residues and are commonly characterized by lower $\mathrm{pH}$. In contrast, at high temperatures 
$\left(<600^{\circ} \mathrm{C}\right)$ the abundance of organic moieties contributes to the production of a higher $\mathrm{pH} \mathrm{BC}$. It was concluded that pyrolysis temperature (and the BC-related characteristics associated with temperature) is the single most important factor that determines how the microbial communities are influenced [144]. Overall there is a consensus that BCs foster the growth and maintenance of soil microbial communities [91,145-147].

\subsubsection{Fungi}

In terms of their abundance and diversity, both beneficial [148-150] and detrimental [91,151-153] effects of $\mathrm{BC}$ on fungal communities have been reported. In comparison to bacteria, fungi respond differently to organic and inorganic treatments. Soil bacteria act as better indicators of soil fertility than soil fungi [154]. The mechanisms for improved fungal diversity and abundance appear to be correlated more with the physical micro-structure of $\mathrm{BC}$ and the recalcitrant organic carbon than other factors. This was demonstrated in a study where corn straw $\mathrm{BC}\left(500^{\circ} \mathrm{C}\right)$ derived aqueous extractable substances, organic extractable substances, and the remaining solid $B C$ were tested [155]. It has been hypothesized that $\mathrm{BC}$ addition preferably fosters bacterial communities over fungal communities. The bacteria may starve the fungi of $C$ and therefore outcompete them [151].

It was demonstrated that fungal diversity was lowered in soybean and rice straw $\mathrm{BC}\left(500^{\circ} \mathrm{C}\right)$ soils compared to controls although individual order, family, genus, and species level fungal communities were affected differently [156]. These outcomes could be a result of the "unbalanced competition" theory. This theory describes the phenomena of saprotrophs exponentially increasing their abundance due to the easily mineralizable carbon found in BC therefore leading to an overall decrease of other fungal groups and potentially suppressing their abundance and diversity [157]. Other speculations underlying decreased fungal diversity and population include the high levels of organic compounds, mineral elements, and higher soil $\mathrm{pH}$ due to BC amendment [158].

\subsubsection{Bacteria}

The microbial community consisting of bacteria tend to respond positively to $\mathrm{BC}$, as several studies have reported a significant increase in abundance, diversity, after BC application, especially in the rhizosphere soil [158-161]. For example, an increase in specific bacterial families and species such as phosphorous solubilizing [162], nitrifiers [163], and $\mathrm{N}$-fixing and denitrifiers [164] was reported with Malus pumila woodchip BC $\left(500^{\circ} \mathrm{C}\right)$, Eucalyptus saligna hardwood BC $\left(550^{\circ} \mathrm{C}\right)$, and sugar maple wood $\mathrm{BC}\left(400^{\circ} \mathrm{C}\right)$ soil amendment, respectively. Additional studies found only modest or no differences [136,155,164,165]. The change in the composition of bacterial communities after incorporation of $\mathrm{BC}$ in soil is highly dependent on the preexisting bacterial community, soil type, and overall BC characteristics.

Generally, the gram-negative bacterial community are favored in the nutrient-enriched BCamended soils and initially predominate the soil environment since they perform specific and narrow functions. They outcompete gram-positive bacteria that rely on recalcitrant $C$ as their main energy source. Gram-positive bacteria become the dominant bacteria type over time due to BC's ability to form stable aggregates with soil organic matter (SOM) [144]. Utilizing sugarcane-derived $\mathrm{BC}\left(450^{\circ} \mathrm{C}\right)$, it was found that bacterial populations increased significantly while fungal populations were significantly reduced in heavy-metal contaminated soils. This was possibly due to the enhanced heavy metal immobilization by the BC addition, although other factors may have contributed to the 
observations [158]. Similar results with wood (fir, cedar) $\mathrm{BC}\left(450^{\circ} \mathrm{C}-550^{\circ} \mathrm{C}\right)$ indicated a significant shift towards a bacteria-dominated microbial community in a short-term study ( 3 months) and was attributed to the increased release of labile $C$ from the BC or stable SOM-BC aggregates [91]. A study utilizing bamboo $\mathrm{BC}\left(500^{\circ} \mathrm{C}\right)$ provided further support for the concept that bacteria are more sensitive to $\mathrm{BC}$ compared to the fungal community, mostly due to increased $\mathrm{pH}$ with increasing $\mathrm{BC}$ addition [166]. These results indicate that alkaline conditions due to BC amendment (liming effect) favor and promote bacterial growth and may inhibit fungal growth.

The high complexity of BC-soil interactions and microbial community dynamics leaves many 'gray areas' in this field that require further investigation. However, assessing the long-term effects of BC-amended soils and microbial population diversity and activity are highly recommended for future studies. Research has indicated that the BC surface and pores can be inundated with plant exudates and dead cells, inorganic and organic complexes, and larger soil microorganisms. These factors may reduce the total available space for microbial colonization of aged BCs over time [167].

\subsection{Abiotic and biotic stressors}

\subsubsection{Heavy Metals}

Soil contamination with organic and inorganic toxins increases environmental and agricultural risks and poses a threat to both plants and humans. Efforts to develop remediation processes that bind the contaminants, limit their mobility and bioavailability, and foster improved soil health are ongoing. Currently, organic materials such as charcoal, soot, kerogen and activated carbon are used as amendments for limiting and reducing the bioavailability of multiple soil contaminants [168,169]. The organic contaminants have been shown to sorb preferentially to the carbonaceous fractions present in soil, limiting their bioavailability [170]. BC has also been shown to reduce the bioavailability of heavy metal contaminants. Several studies analyzed the effect of BC amendment on soils contaminated with heavy metals such as arsenic, cadmium $(\mathrm{Cd})$, copper $(\mathrm{Cu})$, nickel $(\mathrm{Ni})$, lead $(\mathrm{Pb})$, and zinc $(\mathrm{Zn})$ [171-173]. The high surface area of BCs results in more effective contaminant binding; however, one of the recent meta-analysis pointed out that the pyrolysis temperature at which a given $B C$ is produced influences its remediation efficiency and type of contaminant that can be removed [171]. A majority of studies tested the effect of $\mathrm{BC}$ on $\mathrm{Cd}$ pollution and concluded that the higher BC surface area had a smaller effect on Cd bioavailability [171]. The BCs produced at lower temperatures $\left(300^{\circ} \mathrm{C}-500^{\circ} \mathrm{C}\right)$ have higher density of functional groups, while $\mathrm{BC}$ produced at higher temperatures results in larger surface area and lower density of functional group. Another study revealed that $\mathrm{BC}$ produced from wheat straw at $450^{\circ} \mathrm{C}$, with a higher density of functional groups, was more effective in treating $\mathrm{Cd}$ and $\mathrm{Pd}$ contaminated soil [174]. However, BC produced at higher temperature is also more alkaline and results in immobilization of heavy metals in acidic soil via the liming effect. The addition of rice and wheat straw-derived $\mathrm{BC}$ in soils contaminated with $\mathrm{Pb}, \mathrm{Cu}, \mathrm{Cd}$ and $\mathrm{Zn}$ led to reduced mobility and bioavailability of the heavy metals, resulting in increased yields and decreased enrichment of heavy metals in the tested plants [172]. Biochar is also used for remediation of soil from contaminated sites due to rapid industrialization. It has been recently demonstrated that $\mathrm{BC}$ derived from pine wood was able to reduce bioavailability of $\mathrm{Cd}, \mathrm{Pb}$ and $\mathrm{Zn}$ in metalloid-contaminated soils at a smelting site and promoted plant growth [175]. Biochar derived from hardwood $\left(600^{\circ} \mathrm{C}\right)$ was shown to be effective in reducing $\mathrm{Ni}$ and $\mathrm{Zn}$ by $83 \%-93 \%$ in a historically polluted site in the United Kingdom [175]. 
The effect of sewage sludge $\mathrm{BC}$ pyrolyzed at $330^{\circ} \mathrm{C}-500^{\circ} \mathrm{C}$ on alleviating heavy metal toxicity was evaluated. It was observed that with the increase in pyrolysis temperature, the availability of heavy metal in tropical soils was decreased [176]. This might be due to the increased $\mathrm{pH}$, pore size, and surface area in the BC produced at higher temperatures leading to the formation of carbonates, sulfates, phosphates, and metal hydroxides [176]. Due to the reduction in the bioavailability of heavy metal cations, maize yields increased in BC-amended soil in comparison to NPK fertilized soil [176]. Irrigation with untreated wastewater leads to the accumulation of lead, cadmium, zinc, and iron, which can be taken up by plants or leach into ground water, adversely affecting plant growth and human health. In a recent study, the effect of plantain peel-derived biochar $\left(450^{\circ} \mathrm{C}-500^{\circ} \mathrm{C}\right)$ on potato yield was studied in sandy soil irrigated with wastewater [177]. This BC regime resulted in adsorption of soil $\mathrm{Cd}$ and $\mathrm{Zn}$ and reduction of the $\mathrm{Cd}$ level by $69 \%$ and 33\% in tuber flesh [177].

A summary of selected studies reporting the effect of $\mathrm{BC}$ on alleviation of heavy metal toxicity is presented in Table 4. Most of the listed studies were carried out in pots. Therefore, large scale field studies are required to understand the interaction between a particular biochar, soil type, and contaminant. To use biochar for soil remediation, the specific soil and biochar properties must be taken into consideration. Some studies show that certain BC amendment results in high heavy metal immobilization. However, if the mechanism of immobilization is only physical adsorption or cation exchange, these $\mathrm{BC}$ may not be suitable for long-term remediation due to weakly bound metals. $\mathrm{BCs}$ that immobilize heavy metals through precipitation or complex formation should be used for long term remediation.

Table 4. Selected recent studies reporting the effect of BCs derived from various feedstocks on heavy metal remediation in different type of soils.

\begin{tabular}{|c|c|c|c|c|c|c|}
\hline $\begin{array}{l}\text { Exp. } \\
\text { type }\end{array}$ & Soil type & BC feedstock & $\begin{array}{c}\text { Pyrolysis } \\
\text { temperature } \\
\left({ }^{\circ} \mathrm{C}\right)\end{array}$ & $\begin{array}{l}\text { Effect of biochar } \\
\text { amendment }\end{array}$ & Country & 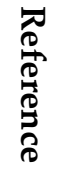 \\
\hline Lab & N/A & $\begin{array}{c}\text { Wood, } \\
\text { Bamboo, Rice } \\
\text { straw and } \\
\text { Walnut shell }\end{array}$ & 500 & $\begin{array}{c}\text { Reduced } \mathrm{Zn}, \mathrm{Cd}, \mathrm{Cu}, \mathrm{Pb} \\
\text { solubility }\end{array}$ & China & [178] \\
\hline Lab & Aridisols & $\begin{array}{l}\text { Woodchip- } \\
\text { derived } \\
\text { biochar }\end{array}$ & 300 & $\begin{array}{l}\text { Reduced extractable Cd, } \\
\text { Pd, Ni and Cu. } \\
\text { Improved antioxidant } \\
\text { enzyme activity. } \\
\text { Increased rapeseed } \\
\text { fresh shoot biomass, } \\
\text { fresh root biomass, total } \\
\text { chlorophyll, total } \\
\text { pigments, carotenoids, } \\
\text { and lycopene } \\
\text { concentration }\end{array}$ & Pakistan & [179] \\
\hline
\end{tabular}




\begin{tabular}{|c|c|c|c|c|c|c|}
\hline $\mathrm{Lab}$ & $\begin{array}{l}\text { Sandy } \\
\text { loam soil }\end{array}$ & $\begin{array}{l}\text { Wood derived } \\
\text { biochar }\end{array}$ & $350-500$ & $\begin{array}{c}\text { Reduction in the } \\
\text { accumulation of } \\
\mathrm{Cu} \text { and } \mathrm{Zn} \text { in Spinach }\end{array}$ & Pakistan & [180] \\
\hline $\mathrm{Lab}$ & N/A & $\begin{array}{c}\text { Switchgrass a } \\
\text { nd poultry } \\
\text { litter } \\
\end{array}$ & 700 & $\begin{array}{l}\text { Decreased the } \mathrm{Zn}, \mathrm{Cd} \\
\text { and } \mathrm{Pb} \text { bio- accessibility }\end{array}$ & USA & [181] \\
\hline $\mathrm{Lab}$ & Paddy soil & Wheat straw & 450 & $\begin{array}{c}\text { Reduced soil Cd } \\
\text { bioavailability }\end{array}$ & China & [182] \\
\hline $\mathrm{Lab}$ & Clay soil & $\begin{array}{l}\text { Corncob } \\
\text { biochar }\end{array}$ & 600 & Reduced lead leaching & China & [183] \\
\hline $\mathrm{Lab}$ & N/A & Wheat straw & $350-650$ & $\begin{array}{c}\text { Lower temperature BC } \\
\text { led to increased Zn (II) } \\
\text { and Cd (II) } \\
\text { immobilization acidic } \\
\text { condition and higher } \\
\text { temperature BC led to } \\
\text { increased Zn (II) and Cd } \\
\text { (II) immobilization } \\
\text { alkaline condition. }\end{array}$ & China & [184] \\
\hline \multirow{3}{*}{ Lab } & \multirow{3}{*}{ N/A } & Manure & 500 & Promoted $\mathrm{Zn}$ and $\mathrm{Cd}$ & \multirow{3}{*}{ USA } & \multirow{3}{*}{185} \\
\hline & & Poultry litter & 500 & $\begin{array}{l}\text { precipitation and } \\
\text { reduced total Cd and } \\
\text { Zn concentrations in } \\
\text { switchgrass shoots and } \\
\text { roots }\end{array}$ & & \\
\hline & & $\begin{array}{l}\text { Lodgepole } \\
\text { pine }\end{array}$ & $500-700$ & $\begin{array}{c}\text { Reduced } \mathrm{Zn} \\
\text { concentration in roots. }\end{array}$ & & \\
\hline \multirow{2}{*}{$\mathrm{Lab}$} & \multirow[b]{2}{*}{ N/A } & $\begin{array}{c}\text { Rice husk } \\
\text { biochar }\end{array}$ & \multirow{2}{*}{550} & \multirow{2}{*}{$\begin{array}{l}\text { Decreased leaching of } \\
\mathrm{Cd}, \mathrm{Cu}, \mathrm{Pb} \text { and } \mathrm{Zn}\end{array}$} & \multirow{2}{*}{$\begin{array}{l}\text { South } \\
\text { Korea }\end{array}$} & \multirow{2}{*}[186]{} \\
\hline & & $\begin{array}{c}\text { Maple leaf } \\
\text { biochar }\end{array}$ & & & & \\
\hline Lab & $\begin{array}{c}\text { Stagnic } \\
\text { Phaeozem }\end{array}$ & Pine wood & N/A & $\begin{array}{c}\text { Decreased heavy metal } \\
\text { accumulation in above } \\
\text { ground parts of } \\
\text { Hordeum vulgare }\end{array}$ & Russia & [187] \\
\hline
\end{tabular}

\subsubsection{Salt}

Salt stress is known to negatively affect soil properties, plant development, and crop productivity due to disturbed soil structure, soil organic matter, microbial activity, and C:N ratio. Salt stress causes oxidative stress in plants, down-regulating antioxidant enzyme activity [188]. Due to excessive salinization, the sodium ions bind to cation exchange sites in soil causing poor crop growth and yields. Although saline soil can be reclaimed by washing or excessively irrigating with 
water to remove excessive salts, it is neither economically nor physically feasible for large fields [189]. On the other hand, sodic soils require treatment with other cations such as calcium to remove excess sodium from cation exchange sites followed by leaching of sodium [189]. The application of organic amendments such as manure or compost has been shown to improve soil fertility by reducing salt stress. In saline soil, the organic amendment improves soil porosity leading to leaching of excess salt. In sodic soil, organic amendments might help by improving the physical characteristics of soil, such as triggering cation exchange with the calcium present in organic amendment and Na present in soil.

Several studies have reported the positive impact of $\mathrm{BC}$ on the nutrient status, conductivity and improved physical and chemical properties of soil. The variable amount of plant nutrients present in the $\mathrm{BC}$ can compensate for the nutrient deficiency and improve fertility of saline soils. For example, sodification raises soil $\mathrm{pH}$ thereby limiting the bioavailability of $\mathrm{P}$. In such soils, BC can act as a P source and improve its availability aiding plant growth [190].

It has been demonstrated that the mixture of hardwood and softwood biochar produced at $500^{\circ} \mathrm{C}$, when mixed with sandy loam soil and irrigated with a saline solution, improved the yield of potato, maize and wheat [191-193]. It was also shown that $\mathrm{BC}$ was able to reduce the $\mathrm{Na}^{+} / \mathrm{K}^{+}$ratio in xylem sap of wheat and potato and reduced Na concentration in maize xylem [193]. When BC produced from wheat straw $\left(350^{\circ} \mathrm{C}-550^{\circ} \mathrm{C}\right)$ was combined with poultry manure, and incorporated into aquientisol soils, a decrease in Na uptake was observed leading to increased biomass in maize and an increase of yield in wheat $[190,194]$. Similarly, rice straw-derived BC $\left(600^{\circ} \mathrm{C}\right)$ alleviated salt stress in paddy soil. There was a significant reduction in bulk density, electrical conductivity, exchangeable $\mathrm{Na}$, and exchangeable chlorine ions in the soil, creating favorable conditions for rice seedling growth [195]. A selection of recent reports in which BC addition was reported to alleviate salt stress are summarized in Table 4.

A majority of the reports support the role of $\mathrm{BC}$ in improving soil health, plant growth and biological properties of soil. It has been reported that BC adsorbs Na salt and improves plant growth; however, salt-affected land is only considered reclaimed if the $\mathrm{Na}$ salts are removed. Therefore, repeated application of $\mathrm{BC}$ might have negative consequences in a case where increased accumulation of Na-salt bound BC aggravates the salinization problem [189]. There is a need for a better understanding of how different BCs interact with different types of salt-affected soils prior to prescription of any recommendations.

Table 5. Selected recent studies reporting the effect of biochar on salt stressed soils.

\begin{tabular}{|c|c|c|c|c|c|c|}
\hline $\begin{array}{c}\text { Exp. } \\
\text { type }\end{array}$ & Soil type & $\begin{array}{c}\text { BC } \\
\text { feedstock }\end{array}$ & $\begin{array}{c}\text { Pyrolysis } \\
\text { temperature } \\
\left({ }^{\circ} \mathrm{C}\right)\end{array}$ & $\begin{array}{c}\text { Effect of biochar } \\
\text { amendment }\end{array}$ & Country & $\begin{array}{c}\text { 离 } \\
\frac{0}{0} \\
\frac{0}{0}\end{array}$ \\
\hline Lab & $\begin{array}{c}\text { Loam } \\
\text { clay }\end{array}$ & Rice straw & $300-600$ & $\begin{array}{c}\text { Reduced bulk density, } \\
\text { electrical conductivity, } \\
\text { exchangeable Na+ and } \\
\text { Cl-. Reduced salt } \\
\text { accumulation in rice } \\
\text { seedlings. }\end{array}$ & China & [195] \\
\hline
\end{tabular}




\begin{tabular}{|c|c|c|c|c|c|c|}
\hline Field & $\begin{array}{c}\text { Not } \\
\text { Reported }\end{array}$ & $\begin{array}{l}\text { Citrus } \\
\text { wood }\end{array}$ & N/A & $\begin{array}{l}\text { Improved plant growth } \\
\text { and productivity. } \\
\text { Improved nutrient } \\
\text { concentration in soil, } \\
\text { dehydration tolerance } \\
\text { and water retention. }\end{array}$ & Egypt & [196] \\
\hline $\mathrm{Lab}$ & $\begin{array}{c}\text { Coastal } \\
\text { soil }\end{array}$ & $\begin{array}{l}\text { Wood } \\
\text { chips }\end{array}$ & 600 & $\begin{array}{c}\text { Improved } \\
\text { photosynthetic } \\
\text { performance and } \\
\text { alleviated oxidative } \\
\text { damage and salt stress. }\end{array}$ & China & [197] \\
\hline $\mathrm{Lab}$ & $\begin{array}{l}\text { Sandy } \\
\text { clay loam }\end{array}$ & Rice straw & 450 & $\begin{array}{l}\text { Mitigated oxidative and } \\
\text { salt stress. Reduced } \mathrm{Cd} \\
\text { and Na concentration in } \\
\text { plant. }\end{array}$ & Pakistan & [198] \\
\hline $\mathrm{Lab}$ & N/A & $\begin{array}{c}\text { Maple } \\
\text { residues }\end{array}$ & 560 & $\begin{array}{l}\text { Improved plant growth } \\
\text { and xylem structure. } \\
\text { Reduced salinity and } \\
\text { plant stress hormones. }\end{array}$ & Iran & [199] \\
\hline $\mathrm{Lab}$ & N/A & Rice straw & 300 & $\begin{array}{c}\text { Increased seed } \\
\text { germination rates of } \\
\text { cowpea. Increased } \\
\text { photosynthetic efficiency } \\
\text { and photosynthetic } \\
\text { pigments. }\end{array}$ & Egypt & 200 \\
\hline
\end{tabular}

\subsubsection{Biotic Stress}

Several recent reports have emerged showing BC to aid plants in countering biotic stresses. It has been suggested that BC-mediated nutrient retention, adsorption, $\mathrm{pH}$ adjustment and increased water holding provides plants with the capacity to respond to pathogens and to counter the effect of toxic metabolites generated by plants [201].

The severity of gray mold, powdery mildew and anthracnose on strawberry plants was evaluated in the presence of $3 \%(\mathrm{w} / \mathrm{w})$ citrus-derived $\mathrm{BC}\left(450^{\circ} \mathrm{C}\right)$. It was observed that greenhouse waste-derived biochar when mixed with coconut fiber: peat reduced the severity of gray mold after disease challenge by $74 \%$ in mature strawberry plants and by $53 \%$ in young strawberry plantlets. Post-disease challenge anthracnose severity was reduced by $39 \%$ - 49\% and powdery mildew severity by $68 \%$ [202]. Both citrus wood and greenhouse waste-derived BC reduced gray mold severity as well. It was observed that BC application induced the expression of genes related to the systematic acquired resistance and induced systemic pathways, which might have contributed to the reduction 
in disease severity [202]. The ability of biochar to absorb pathogenic cell wall-degrading enzymes and toxic metabolites produced by soil pathogen Fusarium oxysporum was also tested with tomato seedlings [201]. The tomato seedlings were treated with 3\% BC produced from eucalyptus wood chips and greenhouse pepper plant waste pyrolyzed at $350^{\circ} \mathrm{C}$ and $600^{\circ} \mathrm{C}$. It was observed that seedlings exposed to enzymes from Fusarium oxysporum and toxic metabolites without BC developed severe disease-like symptoms whereas those symptoms were significantly reduced in the seedlings grown with BC amendment [201]. The exact mechanism of interaction with BC is still unclear; however, it was observed that a majority of the fungal enzymes that were immobilized by BC through adsorption were deactivated [201]. A commercial scale study conducted over a period of 3 years tested the effect of BC on growth and disease resistance in Capsicum annuum L. (sweet pepper) [203]. Pepper seedlings were planted in four combinations of sandy soil amended with biochars produced from greenhouse pepper plant waste and eucalyptus chips. During the first year of growth, it was observed that greenhouse waste-derived $\mathrm{BC}\left(450^{\circ} \mathrm{C}\right)$ reduced severity of powdery mildew by almost $50 \% 168$ days post-planting in comparison with controls. In the second year of the study, the greenhouse waste $\mathrm{BC}\left(350^{\circ} \mathrm{C}\right.$ and $\left.450^{\circ} \mathrm{C}\right)$, showed the highest pepper yield compared to the other treatments and the control [203], in addition to significant reduction in powdery mildew severity. The incidence of plants affected by broad leaf mite was also reduced when amended with greenhouse waste BC. A comparable trend was observed in the third-year trial. Powdery mildew severity was reduced by $25 \%$ in both greenhouse waste and eucalyptus wood chip-derived BC after 160 days of growth [203]. Biochars produced from greenhouse waste $\left(350^{\circ} \mathrm{C}\right)$ and eucalyptus chips $\left(600^{\circ} \mathrm{C}\right)$ was shown to be effective in suppressing crown and root rot in tomato caused by Fusarium oxysporum $\mathrm{f}$. sp. radicis lycopersici [204]. The application of greenhouse waste BC at $0.5 \%, 1 \%$ and $3 \%$ reduced disease severity by $72 \%$. The eucalyptus chip BC also reduced disease severity by $44 \%$ compared to the control plants [204]. There are also some reports where no significant effect of BC on soil borne pathogen suppression was observed [205-207].

The number of studies exploring the role of $\mathrm{BC}$ in pathogen suppression are significantly less than other organic amendments such as compost, peat and crop residue. Hence, additional studies are needed in order to understand the mechanism behind the ability of biochar to suppress pathogens and to be able to prescribe biochar regimens as safe and effective amendment strategies for improvement of plant resistance to soil-borne pathogens.

\section{Impact of Biochar on Crop Production}

Increasing crop yields to feed a burgeoning population is a daunting task in the face of a myriad abiotic and biotic challenges including reduction of arable farmlands, increased plant stressors due to changing climate [208-210]. These issues are especially important in organic production systems where the average crop yields are 5\% - 34\% lower compared to conventional farming [211-214]. The use of biochar in soil remediation can be a useful strategy, especially in degraded soils $[215,216]$. Furthermore, the potential to significantly reduce the organic yield gap through better fertilization regimes has been proposed, suggesting an expanded role for nutrient-rich biochars [217].

A meta-analysis of $\mathrm{BC}$ effects on plant productivity concluded that $\mathrm{BC}$ use holds promise as a method to increase crop yields and could further promote ecosystem services and carbon storage [87,218-220]. It was noted that increased soil N, P, K, reduction of soil acidity due to the liming effect of $\mathrm{BC}$, and improved water relations contributed to various soil and crop responses. In this 
review, a comprehensive literature search was performed with terms "biochar crop productivity yield" for the years 2017-2019 and parsed for minimal criteria (BC feedstock source, pyrolysis temp, retention time, and soil type). The results of the literature search are summarized in Table 6 . The first 330 entries were reviewed with 155 examined for the criteria and 18 were finally selected that fit the minimal criteria.

Table 6. Impact of BC on Crop productivity summarized from a comprehensive literature search.

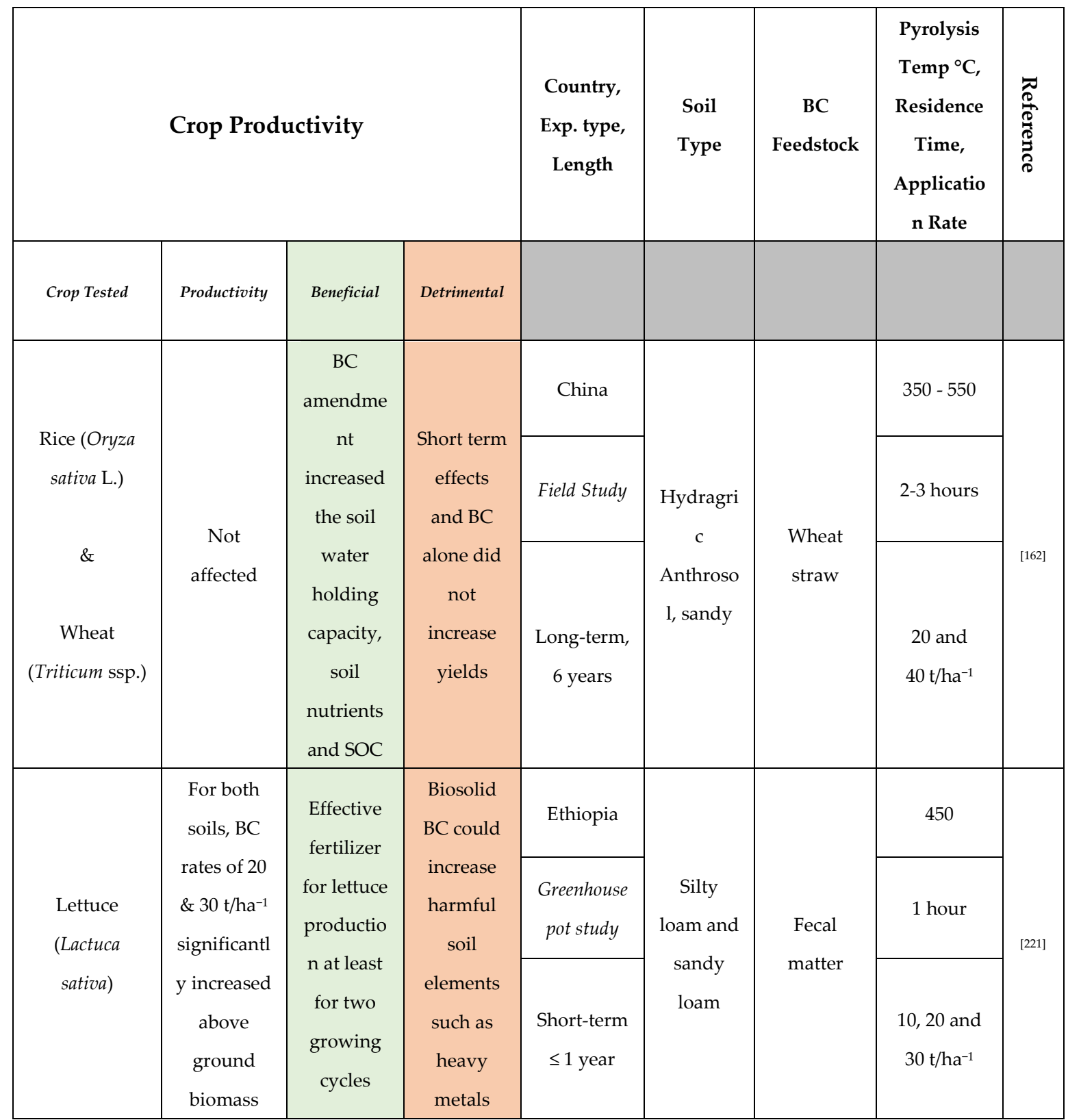




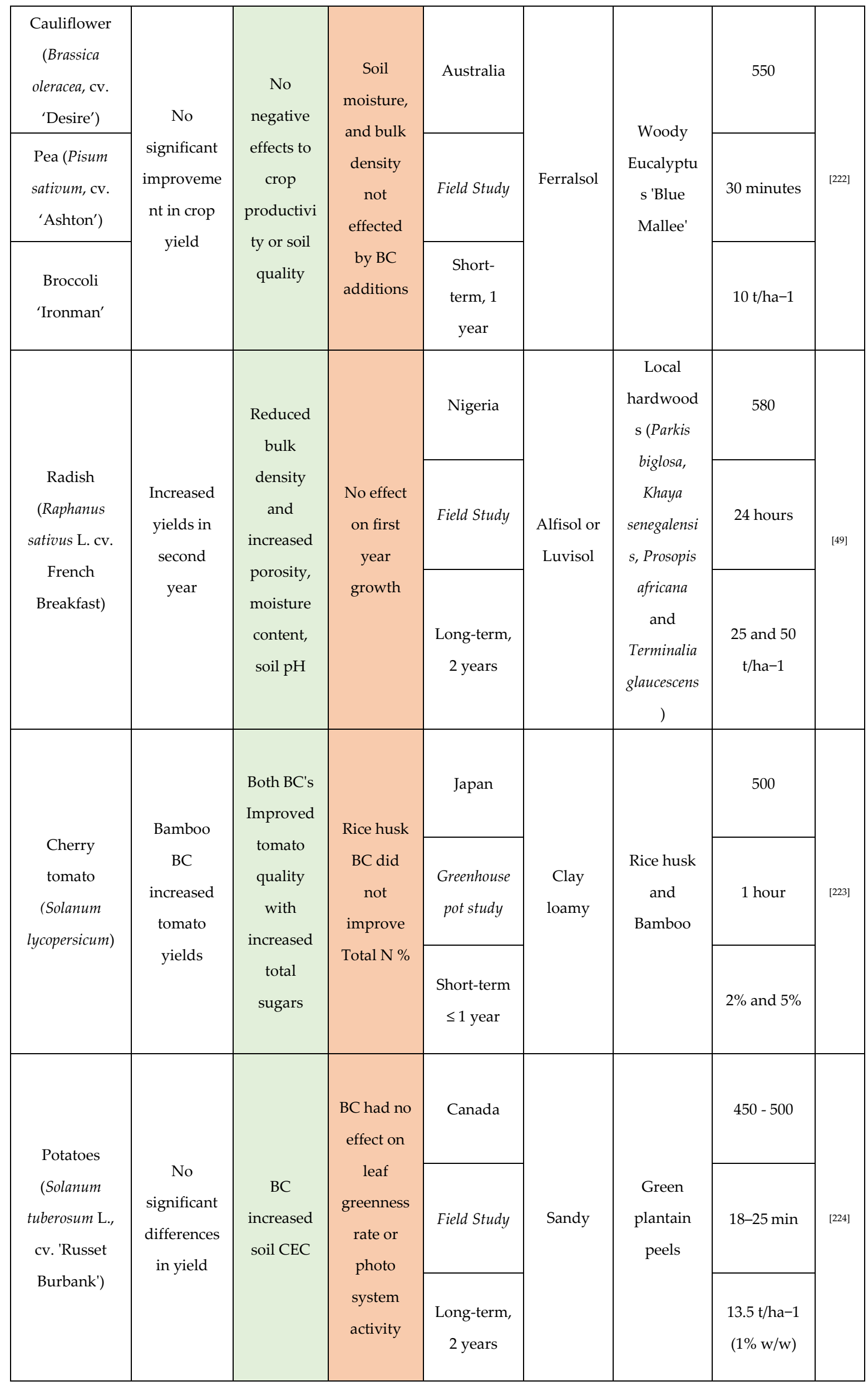




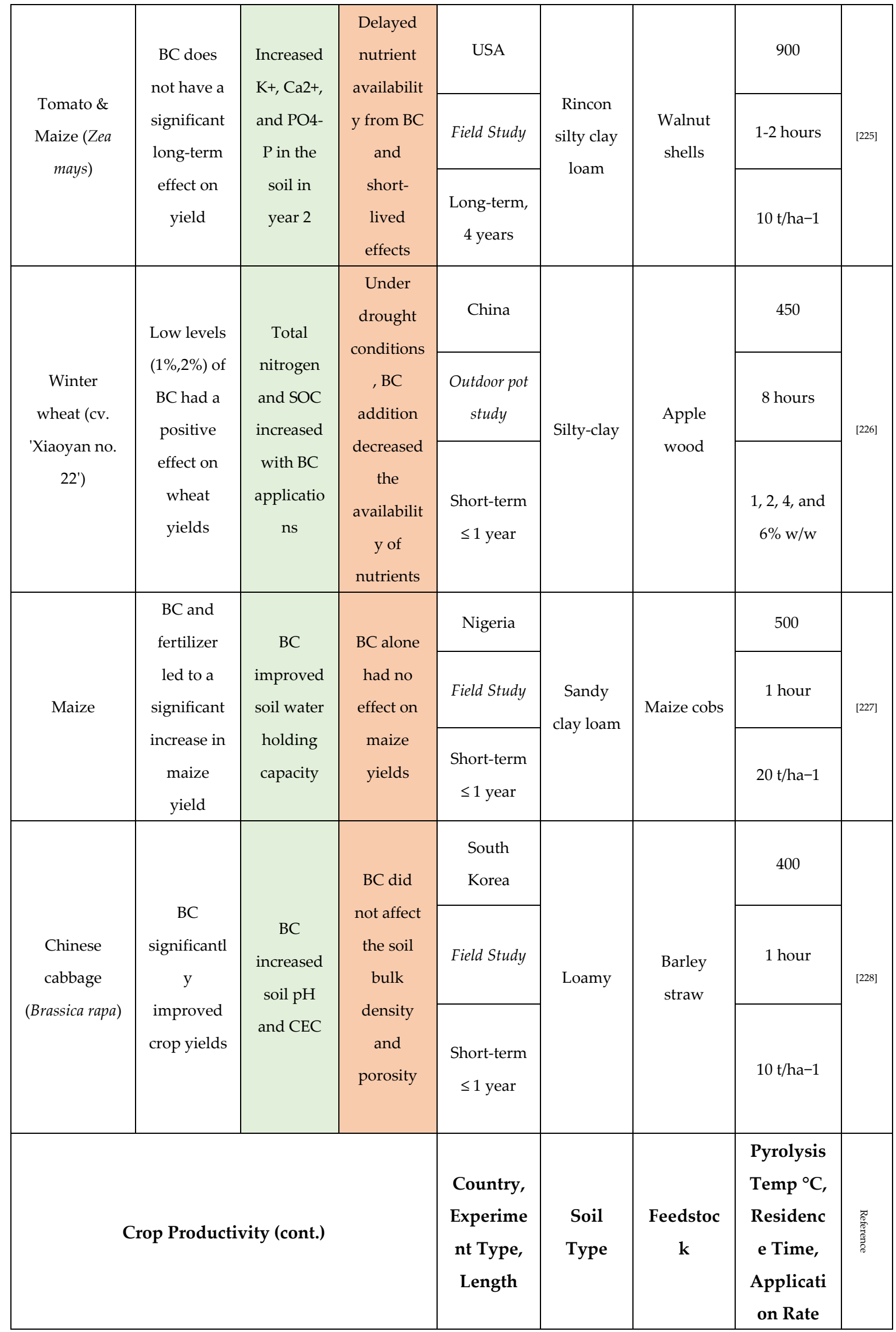




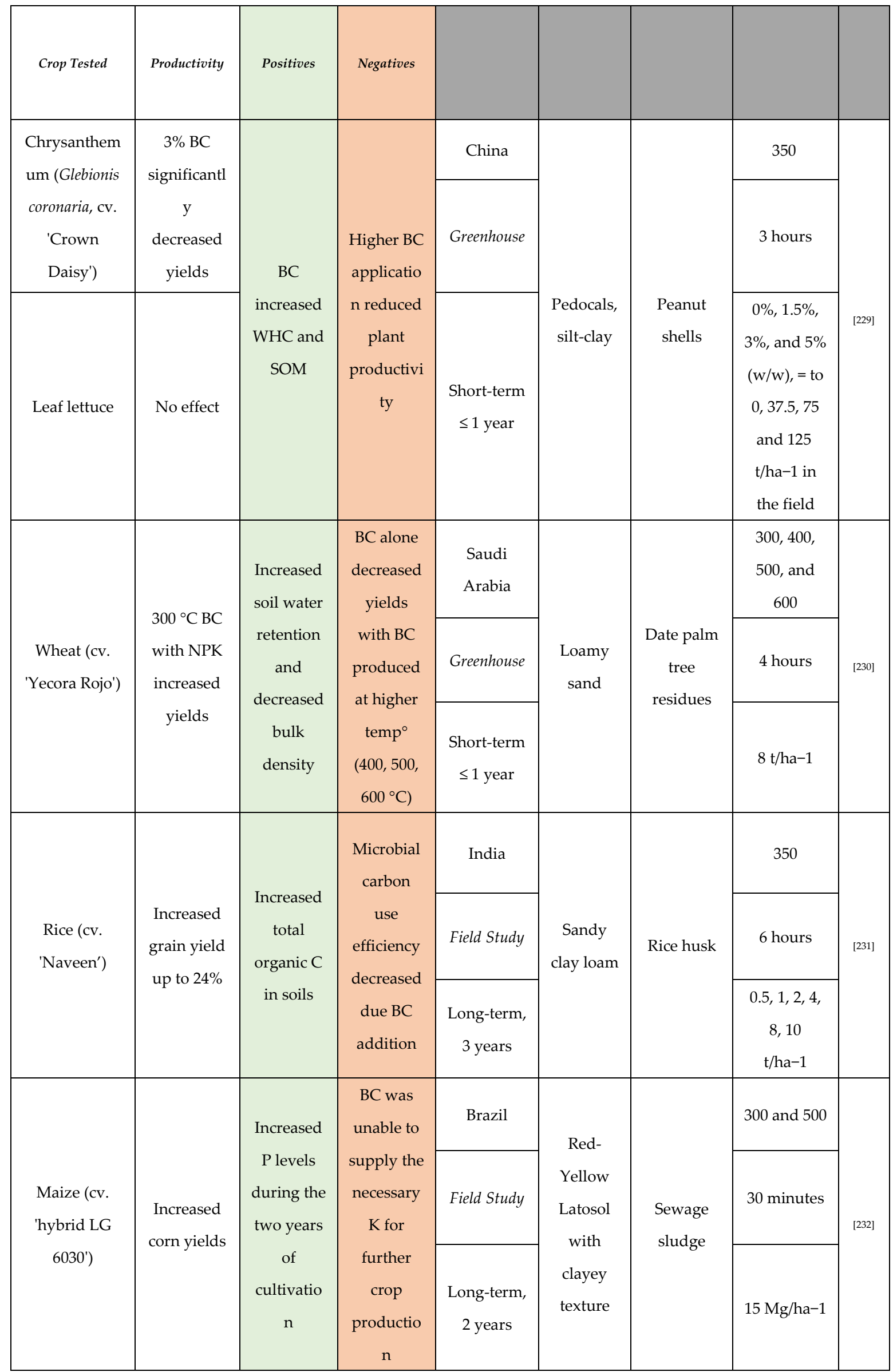




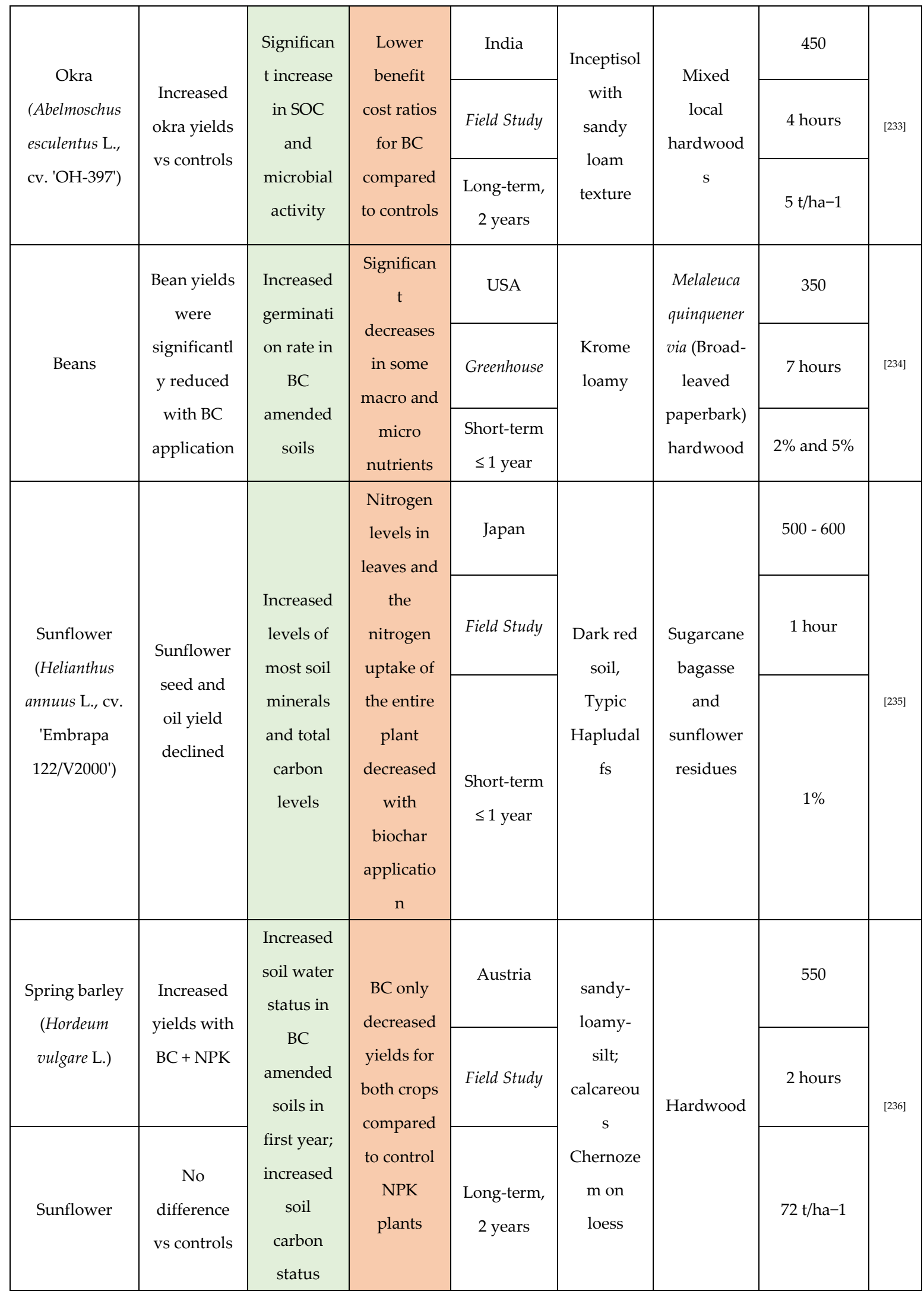

In terms of productivity alone, a majority of the studies reported a beneficial impact of BC on crop yields [49,221,223,226-228,230-233]. Experimental plants included lettuce, cabbage, radish, tomato, wheat, rice, maize, and okra. Soils were amended with BC derived from major feedstock 
sources such as hardwood, manure, and crop residues. Positive results from this mixture of plants and biochars indicates a theoretical system to 'mix and match' crop with BC for optimal productivity. Interestingly, none of the studies included perennial plant species in the experimental design. That is another area where the impact of $\mathrm{BC}$ remains to be assessed.

Due to the range of tested soil conditions, many factors altered by BC amendment were implicated in reported yield gains. For instance, lettuce yields were positively influenced with 20 and $30 \mathrm{t} / \mathrm{ha}^{-1}$ fecal-derived BC $\left(450^{\circ} \mathrm{C}\right)$ [221]. Mineral-enriched BC proved to be an effective fertilizer for two growing cycles in the greenhouse pot study. Additional experiments in greenhouses with leafy crops proved that significant yield increases are possible with BC soil amendment $[237,238]$. Two studies with wheat showed increased yields as a result of soils amended with $1 \%-2 \%$ apple woodderived $\mathrm{BC}\left(450^{\circ} \mathrm{C}\right)$ due to increased nitrogen levels [226] and increased soil water retention with 8 $\mathrm{t} / \mathrm{ha}^{-1}$ date palm tree residue-derived $\mathrm{BC}\left(300-600^{\circ} \mathrm{C}\right)[230]$. The increase in soil organic carbon and the stimulatory effect on microbial communities raised rice yields in soil amended with rice husk $\mathrm{BC}$ $\left(350^{\circ} \mathrm{C}\right)$ [231], and okra yields amended with hardwood-derived $\mathrm{BC}\left(450^{\circ} \mathrm{C}\right)$ [233]. In addition to reporting increases in yields, thse studies also discussed the limitations of field applications of BC.

BC contains key plant nutrients, although at a low level as demonstrated by several studies, and may have led to the lack of a complete plant nutrient profile in the soils to obtain a desirable increase in yields [223]. Multiple studies reported mixed results in terms of crop production $[229,236]$ or described no effect $[162,222,224,225]$. Soil nutrient content and CEC were improved with BC amendment but were short-lived and resulted in comparable crop productivity compared to controls in studies with rice and wheat growing in wheat straw $\mathrm{BC}\left(350^{\circ} \mathrm{C}-550^{\circ} \mathrm{C}\right)$ [162], potatoes with green plantain peel-derived $\mathrm{BC}\left(450^{\circ} \mathrm{C}-500^{\circ} \mathrm{C}\right)$ [224], and tomatoes and maize with walnut shell-derived $\mathrm{BC}\left(900^{\circ} \mathrm{C}\right)$ [225]. Growth of Spring barley and sunflowers was tested with hardwood-derived BC $\left(550^{\circ} \mathrm{C}\right)$ at 72 tha $^{-1}$. The treatments increased barley yields but had no effect on sunflower productivity [236]. The BC-only amendment did increase soil water status and carbon levels; however, increased barley productivity was noted only when BC was mixed with NPK compared to NPK only controls. While increased water holding capacity and soil carbon levels with peanut shell-derived $\mathrm{BC}\left(350^{\circ} \mathrm{C}\right)$ were also reported [229], these alterations did not lead to any effect on lettuce yields.

Undesirable effects on crop productivity following BC soil amendment were also reported in two of the studies [234,235]. Although beans demonstrated an increased rate of germination in BC amended soils, their yields were significantly reduced with hardwood $\mathrm{BC}\left(350^{\circ} \mathrm{C}\right)$ application at $2 \%$ and 5\% [234]. Other studies with legumes reported a gain in yield when grown in BC amended soils. The yields of mash bean improved with sugarcane bagasse $\mathrm{BC}\left(350^{\circ} \mathrm{C}\right)$, with and without chemical fertilizer, due to increased SOC, total N, and decreased bulk density. Importantly, nitrogen fixation increased by $83 \%$ in the biochar-only treatment due to higher nodule numbers [239]. Additionally, fava bean growth with wheat straw-derived $B C\left(500^{\circ} \mathrm{C}\right)$ amendment applied at a $2.5 \% \mathrm{w} / \mathrm{w}$ rate in addition to saltwater irrigation led to significantly increased dry seed yield compared to controls, which was mainly attributed to the high salt sorption capacity of BC [240]. The higher nutrient content in the crop residue-derived BCs reported above may have helped elevate yields compared to controls while the already nutrient poor hardwood-derived BC may have reduced bean yields. While $\mathrm{BC}$ can be a source of nutrients, the complex interactions in the soil environment may have reduced the capacity of available nutrients in the soils inflicting significant yield losses [241]. Additional studies are required to develop a more comprehensive model of BC effect on legume production. 
Other factors potentially responsible for lower productivity include soil nutrient deficiencies found with sugarcane bagasse and sunflower-derived $\mathrm{BC}\left(500^{\circ} \mathrm{C}-600^{\circ} \mathrm{C}\right)$ amended soils [235]. As a result of decreased nitrogen uptake with increasing $\mathrm{BC}$ application, sunflower seed and oil yield saw a significant decrease. The $1 \%$ field application of the BCs may have increased specific communities of bacteria and enhanced certain enzyme activity such as urease, an important enzyme in soil nitrogen status, as reported by a field study with addition of sugarcane bagasse biochar (SCBC) [158]. However, fungal communities suffered due to SCBC addition and final yields of Brassica chinesis L. (pak choi) were reduced compared to controls. It was found that a $4 \%$ application rate of SCBC supported normal plant growth and increased sugar and cane yields [242]. The SOC, soil-water related properties, and nutrient levels were enhanced by SCBC leading to increased plant productivity. Further research is needed to identify BCs appropriate for specific plant species and initial soil characteristics for improved plant growth and development.

Although crop responses were generally positive, the high variability within the listed studies makes it difficult to draw any broad conclusions except that the type and application rate of $B C$ will require customization. The benefits of $\mathrm{BC}$ application mainly consist of increased water holding potential, better nutrient cycling, and increased soil carbon reserves. This may lead to no effect or only minimally increasing yields in the short term, but further testing in the field should illuminate the effects of long-term $B C$ amendment on crop yields. Other regions of industrial agriculture and tropical environments may show a more pronounced $\mathrm{BC}$ effect and may be better at exploiting the advantages of BC. BC application in marginal soils will likely lead to increased crop productivity by increasing the overall soil fertility through $\mathrm{pH}$ and CEC adjustments, better water retention, and increased microbial activity $[243,244]$. Nevertheless, considerable caution should be observed when using extremely heavy rates of BC. The elevated risk of heavy metal contamination due to feedstocks rich in accumulated metals or other phytotoxic compounds could decrease crop productivity with increasing BC applications [245,246].

The overall conclusion is that $\mathrm{BC}$ application is favorable for improving crop productivity sustainably. Certain agricultural systems require different inputs to achieve higher crop yields and designing BC to meet those specific needs could lead to optimized production methods and products.

\section{Future Opportunities}

Analysis of the published literature supports the role of $\mathrm{BC}$ as one of the many viable solutions to soil-related challenges of food production in the face of persistent global issues. While it is not a panacea, the humble porous carbon-composed BC has the ability to physically, biologically and chemically alter soil properties, which has multifarious consequences. There is an opportunity for carbon sequestration and establishing carbon negative cycles with the expanded use of BC. Countering deteriorating soil health due to industrial agriculture, BC amendment can help support higher crop productivity and contribute to improving global food security. The overall impact of BC can be increased by its application on highly weathered and marginal soils that are characterized by depleted nutrients levels, reduced water retention, and lack of competent soil structure.

Future climate models indicate that water stress will be a key driver of reduced crop productivity. $\mathrm{BC}$ has been shown to improve soil water holding capacity, making it a potential candidate for alleviating water stress [247-249]. Finding the right permutation of BC feedstock, application rate, and crop variety are vital for improving agricultural production and reducing the related carbon 
footprint. Initial progress in understanding the effects of BC use has led to the efforts of producing 'designer biochars' which promise to exploit the positive properties and dampen negative effects mainly through feedstock selection but also through chemical, physical, or natural alterations of the BC [87,250-252].

Various studies and published meta-analyses on BC have pointed out the benefits of BC soil amendment; however, there are still several areas that require attention and resolution. Important aspects that affect crop productivity include feedstock sources, various BC production methods, initial soil characteristics, crop variety, and experimental conditions. Others have also reported irregular effects of $B C$ on crop productivity due to these variables [253]. Since it is an irreversible decision to amend soils with BC, the various impacts of augmenting soils are important considerations before conducting field applications [254].

Several articles were not included in the comprehensive literature review due to the omission of key variables that are critical for assessing the overall impact of BC studies. Standardizing BC experiments is vitally important to hypothesis testing, and replicating studies to move the research field forward. All future BC articles should include meticulous descriptions of biochar feedstock sources, pyrolysis temperature, and retention time. Not covered in this review, but still significant, are the various economic factors to be considered before undertaking any large-scale BC applications including: production or acquisition of $\mathrm{BC}$, shipping and transporting, and the time and labor required for field application [233,255]. Additionally, the lack of consistent responses of microbial communities to $\mathrm{BC}$ amendment highlights a knowledge gap regarding the mechanism by which microbes interact with BC. BC has the potential to decrease the bioavailability and efficiency of some herbicides, which is yet another variable that needs consideration [256]. Areas needing further investigation include:

- Biomes underrepresented in the current biochar-associated literature, such as forests and perennial crops (the vast majority of BC studies are directed towards temperate and tropical areas);

- Effects of biochar on non-model crop species (present studies primarily focus on model organisms such as tomato, maize, rice, and wheat);

- Assessment of biochar-amended soil microbial activity through deep meta-genomics approaches;

- Longer-term experiments to understand characteristics of 'aged' BC to assess its temporally evolving properties in soils;

- Development of cost-effective ways to minimize environmental impacts by incorporating organic fertilizer amendments such as BC.

Knowledge generated from the above-mentioned areas of investigation is expected to enable the large-scale utilization of biochars in agriculture, a step towards establishing carbon negative ecosystems.

Author Contributions: Conceptualization - AD, E.T. and R.G.; Resources - A.D.; Writing - review and editing E.T., R.G., A.D.; Supervision - A.D.; Funding acquisition - A.D.

Funding: This work was supported in part by USDA-NIFA Hatch Grant WNP00011 to AD.

Acknowledgements: The authors thank Dr. Seanna Hewitt, Karen Adams and Dr. Richard Sharpe for their critical reading of the manuscript and their feedback. 
Conflicts of Interest: AD serves as a consultant for AgEnergy Solutions - a biochar production startup company based in Spokane, WA, USA. AgEnergy Solutions had no role in the design of the study; in the collection, analyses, or interpretation of data; in the writing of the manuscript, or in the decision to publish the results.

\section{References}

(1) Foley, J. A.; Ramankutty, N.; Brauman, K. A.; Cassidy, E. S.; Gerber, J. S.; Johnston, M.; Mueller, N. D.; O'Connell, C.; Ray, D. K.; West, P. C.; Balzer, C.; Bennett, E. M.; Carpenter, S. R.; Hill, J.; Monfreda, C.; Polasky, S.; Rockström, J.; Sheehan, J.; Siebert, S.; Tilman, D.; Zaks, D. P. M. Solutions for a Cultivated Planet. Nature 2011, 478 (7369), 337-342. https://doi.org/10.1038/nature10452.

(2) Raupach, M. R.; Marland, G.; Ciais, P.; Le Quéré, C.; Canadell, J. G.; Klepper, G.; Field, C. B. Global and Regional Drivers of Accelerating CO2 Emissions. Proc. Natl. Acad. Sci. U. S. A. 2007, 104 (24), 10288-10293. https://doi.org/10.1073/pnas.0700609104.

(3) The Paris Agreement I UNFCCC.

(4) Minasny, B.; Malone, B. P.; McBratney, A. B.; Angers, D. A.; Arrouays, D.; Chambers, A.; Chaplot, V.; Chen, Z.-S.; Cheng, K.; Das, B. S. Soil Carbon 4 per Mille. Geoderma 2017, 292, 5986.

(5) Meinshausen, M.; Meinshausen, N.; Hare, W.; Raper, S. C. B.; Frieler, K.; Knutti, R.; Frame, D. J.; Allen, M. R. Greenhouse-Gas Emission Targets for Limiting Global Warming to 2 C. Nature 2009, 458 (7242), 1158.

(6) Smith, P. Soil Carbon Sequestration and Biochar as Negative Emission Technologies. Glob. Chang. Biol. 2016, 22 (3), 1315-1324. https://doi.org/10.1111/gcb.13178.

(7) Canadell, J. G.; Raupach, M. R. Managing Forests for Climate Change Mitigation. Science. American Association for the Advancement of Science 2008, pp 1456-1457. https://doi.org/10.1126/science.1155458.

(8) Creutzig, F.; Ravindranath, N. H.; Berndes, G.; Bolwig, S.; Bright, R.; Cherubini, F.; Chum, H.; Corbera, E.; Delucchi, M.; Faaij, A. Bioenergy and Climate Change Mitigation: An Assessment. Gcb Bioenergy 2015, 7 (5), 916-944.

(9) Socolow, R.; Desmond, M.; Aines, R.; Blackstock, J.; Bolland, O.; Kaarsberg, T.; Lewis, N.; Mazzotti, M.; Pfeffer, A.; Sawyer, K. Direct Air Capture of CO2 with Chemicals: A Technology Assessment for the APS Panel on Public Affairs; American Physical Society, 2011.

(10) Atafar, Z.; Mesdaghinia, A.; Nouri, J.; Homaee, M.; Yunesian, M.; Ahmadimoghaddam, M.; Mahvi, A. H. Effect of Fertilizer Application on Soil Heavy Metal Concentration. Environ. Monit. Assess. 2010, 160 (1-4), 83.

(11) Wang, J.; Yu, L.; Hu, L.; Chen, G.; Xin, H.; Feng, X. Ambient Ammonia Synthesis via Palladium-Catalyzed Electrohydrogenation of Dinitrogen at Low Overpotential. Nat. Commun. 2018, 9 (1), 1-7. https://doi.org/10.1038/s41467-018-04213-9.

(12) Smith, N. J. H. The Amazon River Forest: A Natural History of Plants, Animals, and People. OUP Cat. 1999.

(13) Skjemstad, J. O.; Reicosky, D. C.; Wilts, A. R.; McGowan, J. A. Charcoal Carbon in US Agricultural Soils. Soil Sci. Soc. Am. J. 2002, 66 (4), 1249-1255.

(14) Glaser, B.; Haumaier, L.; Guggenberger, G.; Zech, W. The'Terra Preta'phenomenon: A Model for Sustainable Agriculture in the Humid Tropics. Naturwissenschaften 2001, 88 (1), 37-41.

(15) Zech, W.; Haumaier, L.; Reinhold, H. Ecological Aspects of Soil Organic Matter in Tropical 
Land Use. Humic Subst. soil Crop Sci. Sel. readings 1990, No. humicsubstances, 187-202.

(16) Smith, N. J. H. Anthrosols and Human Carrying Capacity in Amazonia. Ann. Assoc. Am. Geogr. 1980, 70 (4), 553-566.

(17) Woolf, D.; Amonette, J. E.; Street-Perrott, F. A.; Lehmann, J.; Joseph, S. Sustainable Biochar to Mitigate Global Climate Change. Nat. Commun. 2010, 1, 56.

(18) Al Arni, S. Comparison of Slow and Fast Pyrolysis for Converting Biomass into Fuel. Renew. Energy 2018, 124, 197-201.

(19) Suliman, W.; Harsh, J. B.; Abu-Lail, N. I.; Fortuna, A.-M.; Dallmeyer, I.; Garcia-Perez, M. Influence of Feedstock Source and Pyrolysis Temperature on Biochar Bulk and Surface Properties. Biomass and Bioenergy 2016, 84, 37-48.

(20) Fu, P.; Hu, S.; Xinag, J.; Sun, L.; Yang, T.; Zhang, A.; Wang, Y.; Chen, G. Effects of Pyrolysis Temperature on Characteristics of Porosity in Biomass Chars. In 2009 International Conference on Energy and Environment Technology; IEEE, 2009; Vol. 1, pp 109-112.

(21) Lehmann, J.; Joseph, S. Biochar for Environmental Management: Science, Technology and Implementation; Routledge, 2015.

(22) Dai, Z.; Zhang, X.; Tang, C.; Muhammad, N.; Wu, J.; Brookes, P. C.; Xu, J. Potential Role of Biochars in Decreasing Soil Acidification-A Critical Review. Sci. Total Environ. 2017, 581, 601611.

(23) Yuan, J.-H.; Xu, R.-K.; Zhang, H. The Forms of Alkalis in the Biochar Produced from Crop Residues at Different Temperatures. Bioresour. Technol. 2011, 102 (3), 3488-3497.

(24) Dai, Z.; Brookes, P. C.; He, Y.; Xu, J. Increased Agronomic and Environmental Value Provided by Biochars with Varied Physiochemical Properties Derived from Swine Manure Blended with Rice Straw. J. Agric. Food Chem. 2014, 62 (44), 10623-10631.

(25) Zhao, L.; Cao, X.; Mašek, O.; Zimmerman, A. Heterogeneity of Biochar Properties as a Function of Feedstock Sources and Production Temperatures. J. Hazard. Mater. 2013, 256-257, 1-9. https://doi.org/10.1016/J.JHAZMAT.2013.04.015.

(26) Flowers, M. D.; Lal, R. Axle Load and Tillage Effects on Soil Physical Properties and Soybean Grain Yield on a Mollic Ochraqualf in Northwest Ohio. Soil Tillage Res. 1998, 48 (1-2), 21-35.

(27) Bruand, A.; Gilkes, R. J. Subsoil Bulk Density and Organic Carbon Stock in Relation to Land Use for a Western Australian Sodosol. Soil Res. 2002, 40 (6), 999-1010.

(28) Beutler, A. N.; Centurion, J. F.; Silva, A. P. da; Centurion, M. A. P. da C.; Leonel, C. L.; Freddi, O. da S. Soil Compaction by Machine Traffic and Least Limiting Water Range Related to Soybean Yield. Pesqui. Agropecu. Bras. 2008, 43 (11), 1591-1600.

(29) Ramazan, M.; Khan, G. D.; Hanif, M.; Ali, S. Impact of Soil Compaction on Root Length and Yield of Corn (Zea Mays) under Irrigated Condition. Middle-East J. Sci. Res. 2012, 11 (3), 382385.

(30) Omondi, M. O.; Xia, X.; Nahayo, A.; Liu, X.; Korai, P. K.; Pan, G. Quantification of Biochar Effects on Soil Hydrological Properties Using Meta-Analysis of Literature Data. Geoderma 2016, $274,28-34$.

(31) Blanco-Canqui, H. Biochar and Soil Physical Properties. Soil Sci. Soc. Am. J. 2017, 81 (4), 687711.

(32) Obour, P. B.; Danso, E.; Yakubu, A.; Abenney-Mickson, S.; Sabi, E.; Darrah, Y.; Arthur, E. Water Retention, Air Exchange and Pore Structure Characteristics after 3 Years of Rice Straw 
Biochar Application to an Acrisol. Soil Sci. Soc. Am. J. 2019, 83 (6), 1-27. https://doi.org/10.2136/sssaj2019.07.0230.

(33) de Jesus Duarte, S.; Glaser, B.; Pellegrino Cerri, C. Effect of Biochar Particle Size on Physical, Hydrological and Chemical Properties of Loamy and Sandy Tropical Soils. Agronomy 2019, 9 (4), 165. https://doi.org/10.3390/agronomy9040165.

(34) Verheijen, F. G. A.; Zhuravel, A.; Silva, F. C.; Amaro, A.; Ben-Hur, M.; Keizer, J. J. The Influence of Biochar Particle Size and Concentration on Bulk Density and Maximum Water Holding Capacity of Sandy vs Sandy Loam Soil in a Column Experiment. Geoderma 2019, 347, 194-202. https://doi.org/10.1016/j.geoderma.2019.03.044.

(35) Rahim, H. U.; Mian, I. A.; Arif, M.; Rahim, Z. U.; Ahmad, S.; Khan, Z.; Zada, L.; Khan, M. A.; Haris, M. 3. Residual Effect of Biochar and Summer Legumes on Soil Physical Properties and Wheat Growth. Pure Appl. Biol. 2019, 8 (1), 16-26.

(36) You, J.; Sun, L.; Liu, X.; Hu, X.; Xu, Q. Effects of Sewage Sludge Biochar on Soil Characteristics and Crop Yield in Loamy Sand Soil. Polish J. Environ. Stud. 2019, 28 (4).

(37) Duarte, S. D. J.; Glaser, B.; De Lima, R. P.; Cerri, C. P. Chemical, Physical, and Hydraulic Properties as Affected by One Year of Miscanthus Biochar Interaction with Sandy and Loamy Tropical Soils. Soil Syst. 2019, 3 (2), 24.

(38) Nikravesh, I.; Boroomandnasab, S.; Abd Ali Naseri, A. S. M. Wheat Straw Biochar Application to Loam-Sand Soil: Impact on Yield Components of Summer Maize and Some Soil Properties. World 2019, $8(1)$, 54-60.

(39) Zhou, H.; Fang, H.; Zhang, Q.; Wang, Q.; Chen, C.; Mooney, S. J.; Peng, X.; Du, Z. Biochar Enhances Soil Hydraulic Function but Not Soil Aggregation in a Sandy Loam. Eur. J. Soil Sci. 2019, 70 (2), 291-300.

(40) Zhang, L.; Jing, Y.; Chen, G.; Wang, X.; Zhang, R. Improvement of Physical and Hydraulic Properties of Desert Soil with Amendment of Different Biochars. J. Soils Sediments 2019, 19 (7), 2984-2996.

(41) Kätterer, T.; Roobroeck, D.; Andrén, O.; Kimutai, G.; Karltun, E.; Kirchmann, H.; Nyberg, G.; Vanlauwe, B.; de Nowina, K. R. Biochar Addition Persistently Increased Soil Fertility and Yields in Maize-Soybean Rotations over 10 Years in Sub-Humid Regions of Kenya. F. Crop. Res. 2019, 235, 18-26.

(42) Badawi, M. A. Production of Biochar from Date Palm Fronds and Its Effects on Soil Properties. By-Products Palm Trees Their Appl. 2019, 11, 159.

(43) Tanure, M. M. C.; da Costa, L. M.; Huiz, H. A.; Fernandes, R. B. A.; Cecon, P. R.; Pereira Junior, J. D.; da Luz, J. M. R. Soil Water Retention, Physiological Characteristics, and Growth of Maize Plants in Response to Biochar Application to Soil. Soil Tillage Res. 2019, 192, 164-173. https://doi.org/10.1016/j.still.2019.05.007.

(44) Lentz, R. D.; Ippolito, J. A.; Lehrsch, G. A. Biochar, Manure, and Sawdust Alter Long-Term Water Retention Dynamics in Degraded Soil. Soil Sci. Soc. Am. J. 2019, 83 (5), 1491-1501.

(45) Huang, M.; Zhang, Z.; Zhai, Y.; Lu, P.; Zhu, C. Effect of Straw Biochar on Soil Properties and Wheat Production under Saline Water Irrigation. Agronomy 2019, 9 (8), 457.

(46) Xiu, L.; Zhang, W.; Sun, Y.; Wu, D.; Meng, J.; Chen, W. Effects of Biochar and Straw Returning on the Key Cultivation Limitations of Albic Soil and Soybean Growth over 2 Years. Catena 2019, 173, 481-493. 
(47) Horák, J.; Šimanský, V.; Igaz, D. Biochar and Biochar with N Fertilizer Impact on Soil Physical Properties in a Silty Loam Haplic Luvisol. J. Ecol. Eng. 2019, 20 (7).

(48) Baiamonte, G.; Crescimanno, G.; Parrino, F.; De Pasquale, C. Effect of Biochar on the Physical and Structural Properties of a Sandy Soil. Catena 2019, 175, 294-303.

(49) Adekiya, A. O.; Agbede, T. M.; Aboyeji, C. M.; Dunsin, O.; Simeon, V. T. Effects of Biochar and Poultry Manure on Soil Characteristics and the Yield of Radish. Sci. Hortic. (Amsterdam). 2019, 243, 457-463. https://doi.org/10.1016/J.SCIENTA.2018.08.048.

(50) Dai, Y.; Zheng, H.; Jiang, Z.; Xing, B. Combined Effects of Biochar Properties and Soil Conditions on Plant Growth: A Meta-Analysis. Sci. Total Environ. 2020, 713, 136635. https://doi.org/https://doi.org/10.1016/j.scitotenv.2020.136635.

(51) Wang, D.; Li, C.; Parikh, S. J.; Scow, K. M. Impact of Biochar on Water Retention of Two Agricultural Soils - A Multi-Scale Analysis. Geoderma 2019, 340, 185-191. https://doi.org/10.1016/J.GEODERMA.2019.01.012.

(52) Hardie, M.; Clothier, B.; Bound, S.; Oliver, G.; Close, D. Does Biochar Influence Soil Physical Properties and Soil Water Availability? Plant Soil 2014, 376 (1), 347-361. https://doi.org/10.1007/s11104-013-1980-x.

(53) Rogovska, N.; Laird, D. A.; Rathke, S. J.; Karlen, D. L. Biochar Impact on Midwestern Mollisols and Maize Nutrient Availability. Geoderma 2014, 230, 340-347.

(54) Usowicz, B.; Lipiec, J.; Łukowski, M.; Marczewski, W.; Usowicz, J. The Effect of Biochar Application on Thermal Properties and Albedo of Loess Soil under Grassland and Fallow. Soil Tillage Res. 2016, 164, 45-51.

(55) Xiao, Q.; Zhu, L.-X.; Zhang, H.-P.; Li, X.-Y.; Shen, Y.-F.; Li, S.-Q. Soil Amendment with Biochar Increases Maize Yields in a Semi-Arid Region by Improving Soil Quality and Root Growth. Crop Pasture Sci. 2016, 67 (5), 495-507.

(56) Pratiwi, E. P. A.; Shinogi, Y. Rice Husk Biochar Application to Paddy Soil and Its Effects on Soil Physical Properties, Plant Growth, and Methane Emission. Paddy water Environ. 2016, 14 (4), 521-532.

(57) Obia, A.; Mulder, J.; Martinsen, V.; Cornelissen, G.; Børresen, T. In Situ Effects of Biochar on Aggregation, Water Retention and Porosity in Light-Textured Tropical Soils. Soil Tillage Res. 2016, 155, 35-44.

(58) Liu, Z.; Dugan, B.; Masiello, C. A.; Barnes, R. T.; Gallagher, M. E.; Gonnermann, H. Impacts of Biochar Concentration and Particle Size on Hydraulic Conductivity and DOC Leaching of Biochar-Sand Mixtures. J. Hydrol. 2016, 533, 461-472.

(59) Chen, B.; Han, M. Y.; Peng, K.; Zhou, S. L.; Shao, L.; Wu, X. F.; Wei, W. D.; Liu, S. Y.; Li, Z.; Li, J. S.; Chen, G. Q. Global Land-Water Nexus: Agricultural Land and Freshwater Use Embodied in Worldwide Supply Chains. Sci. Total Environ. 2018, 613-614, 931-943. https://doi.org/10.1016/J.SCITOTENV.2017.09.138.

(60) Fischer, B. M. C.; Manzoni, S.; Morillas, L.; Garcia, M.; Johnson, M. S.; Lyon, S. W. Improving Agricultural Water Use Efficiency with Biochar - A Synthesis of Biochar Effects on Water Storage and Fluxes across Scales. Sci. Total Environ. 2019, 657, 853-862. https://doi.org/10.1016/J.SCITOTENV.2018.11.312.

(61) Basso, A. S.; Miguez, F. E.; Laird, D. A.; Horton, R.; Westgate, M. Assessing Potential of Biochar for Increasing Water-Holding Capacity of Sandy Soils. GCB Bioenergy 2013, 5 (2), 132 
143. https://doi.org/10.1111/gcbb.12026.

(62) Laghari, M.; Naidu, R.; Xiao, B.; Hu, Z.; Mirjat, M. S.; Hu, M.; Kandhro, M. N.; Chen, Z.; Guo, D.; Jogi, Q.; Abudi, Z. N.; Fazal, S. Recent Developments in Biochar as an Effective Tool for Agricultural Soil Management: A Review. J. Sci. Food Agric. 2016, 96 (15), 4840-4849. https://doi.org/10.1002/jsfa.7753.

(63) Obia, A.; Cornelissen, G.; Martinsen, V.; Smebye, A. B.; Mulder, J. Conservation Tillage and Biochar Improve Soil Water Content and Moderate Soil Temperature in a Tropical Acrisol. Soil Tillage Res. 2020, 197. https://doi.org/10.1016/j.still.2019.104521.

(64) Kinney, T. J.; Masiello, C. A.; Dugan, B.; Hockaday, W. C.; Dean, M. R.; Zygourakis, K.; Barnes, R. T. Hydrologic Properties of Biochars Produced at Different Temperatures. Biomass and Bioenergy 2012, 41, 34-43. https://doi.org/10.1016/j.biombioe.2012.01.033.

(65) Lei, O.; Zhang, R. Effects of Biochars Derived from Different Feedstocks and Pyrolysis Temperatures on Soil Physical and Hydraulic Properties. J. Soils Sediments 2013, 13 (9), 15611572. https://doi.org/10.1007/s11368-013-0738-7.

(66) Rafiq, M. K.; Bachmann, R. T.; Rafiq, M. T.; Shang, Z.; Joseph, S.; Long, R. Influence of Pyrolysis Temperature on Physico-Chemical Properties of Corn Stover (Zea Mays L.) Biochar and Feasibility for Carbon Capture and Energy Balance. PLoS One 2016, 11 (6), e0156894. https://doi.org/10.1371/journal.pone.0156894.

(67) Gray, M.; Johnson, M. G.; Dragila, M. I.; Kleber, M. Water Uptake in Biochars: The Roles of Porosity and Hydrophobicity. Biomass and Bioenergy 2014, 61, 196-205. https://doi.org/10.1016/j.biombioe.2013.12.010.

(68) Mao, J.; Zhang, K.; Chen, B. Linking Hydrophobicity of Biochar to the Water Repellency and Water Holding Capacity of Biochar-Amended Soil. Environ. Pollut. 2019, 253, 779-789. https://doi.org/10.1016/j.envpol.2019.07.051.

(69) Suliman, W.; Harsh, J. B.; Abu-Lail, N. I.; Fortuna, A. M.; Dallmeyer, I.; Garcia-Pérez, M. The Role of Biochar Porosity and Surface Functionality in Augmenting Hydrologic Properties of a Sandy Soil. Sci. Total Environ. 2017, 574, 139-147. https://doi.org/10.1016/j.scitotenv.2016.09.025.

(70) Batista, E. M. C. C.; Shultz, J.; Matos, T. T. S.; Fornari, M. R.; Ferreira, T. M.; Szpoganicz, B.; De Freitas, R. A.; Mangrich, A. S. Effect of Surface and Porosity of Biochar on Water Holding Capacity Aiming Indirectly at Preservation of the Amazon Biome. Sci. Rep. 2018, 8 (1), 1-9. https://doi.org/10.1038/s41598-018-28794-z.

(71) Kameyama, K.; Miyamoto, T.; Iwata, Y. The Preliminary Study of Water-Retention Related Properties of Biochar Produced from Various Feedstock at Different Pyrolysis Temperatures. Materials (Basel). 2019, 12 (11), 1732. https://doi.org/10.3390/ma12111732.

(72) Barnes, R. T.; Gallagher, M. E.; Masiello, C. A.; Liu, Z.; Dugan, B. Biochar-Induced Changes in Soil Hydraulic Conductivity and Dissolved Nutrient Fluxes Constrained by Laboratory Experiments. PLoS One 2014, 9 (9). https://doi.org/10.1371/journal.pone.0108340.

(73) Aller, D.; Rathke, S.; Laird, D.; Cruse, R.; Hatfield, J. Impacts of Fresh and Aged Biochars on Plant Available Water and Water Use Efficiency. Geoderma 2017, 307, 114-121. https://doi.org/10.1016/j.geoderma.2017.08.007.

(74) Razzaghi, F.; Obour, P. B.; Arthur, E. Does Biochar Improve Soil Water Retention? A $\begin{array}{llll}\text { Systematic Review and } & \text { Meta-Analysis. }\end{array}$ 
https://doi.org/10.1016/j.geoderma.2019.114055.

(75) Marshall, J.; Muhlack, R.; Morton, B. J.; Dunnigan, L.; Chittleborough, D.; Kwong, C. W. Pyrolysis Temperature Effects on Biochar-Water Interactions and Application for Improved Water Holding Capacity in Vineyard Soils. Soil Syst. 2019, 3 (2), 27. https://doi.org/10.3390/soilsystems3020027.

(76) Zhang, X.; Cai, X. Climate Change Impacts on Global Agricultural Land Availability. Environ. Res. Lett. 2011, 6 (1), 014014. https://doi.org/10.1088/1748-9326/6/1/014014.

(77) Nguyen, T. T. N.; Xu, C.-Y.; Tahmasbian, I.; Che, R.; Xu, Z.; Zhou, X.; Wallace, H. M.; Bai, S. $\mathrm{H}$. Effects of Biochar on Soil Available Inorganic Nitrogen: A Review and Meta-Analysis. Geoderma 2017, 288, 79-96. https://doi.org/10.1016/J.GEODERMA.2016.11.004.

(78) Gupta, R. K.; Hussain, A.; Yadvinder-Singh; Sooch, S. S.; Kang, J. S.; Sharma, S.; Dheri, G. S. Rice Straw Biochar Improves Soil Fertility, Growth, and Yield of Rice-Wheat System on a Sandy Loam Soil. Exp. Agric. 2019, 56 (1), 118-131. https://doi.org/10.1017/S0014479719000218.

(79) Khan, M.; Fatima, K.; Ahmad, R.; Younas, R.; Rizwan, M.; Azam, M.; Abadin, Z. ul; Ali, S. Comparative Effect of Mesquite Biochar, Farmyard Manure, and Chemical Fertilizers on Soil Fertility and Growth of Onion (Allium Cepa L.). Arab. J. Geosci. 2019, 12 (18), 1-7. https://doi.org/10.1007/s12517-019-4734-0.

(80) Borchard, N.; Schirrmann, M.; Cayuela, M. L.; Kammann, C.; Wrage-Mönnig, N.; Estavillo, J. M.; Fuertes-Mendizábal, T.; Sigua, G.; Spokas, K.; Ippolito, J. A.; Novak, J. Biochar, Soil and Land-Use Interactions That Reduce Nitrate Leaching and N2O Emissions: A Meta-Analysis. Sci. Total Environ. 2019, 651, 2354-2364. https://doi.org/10.1016/J.SCITOTENV.2018.10.060.

(81) Yao, Y.; Gao, B.; Zhang, M.; Inyang, M.; Zimmerman, A. R. Effect of Biochar Amendment on Sorption and Leaching of Nitrate, Ammonium, and Phosphate in a Sandy Soil. Chemosphere 2012, 89 (11), 1467-1471. https://doi.org/10.1016/J.CHEMOSPHERE.2012.06.002.

(82) Chen, Q.; Qin, J.; Sun, P.; Cheng, Z.; Shen, G. Cow Dung-Derived Engineered Biochar for Reclaiming Phosphate from Aqueous Solution and Its Validation as Slow-Release Fertilizer in Soil-Crop System. J. Clean. Prod. 2018, 172, 2009-2018. https://doi.org/10.1016/J.JCLEPRO.2017.11.224.

(83) Qiu, G.; Zhao, Y.; Wang, H.; Tan, X.; Chen, F.; Hu, X. Biochar Synthesized via Pyrolysis of Broussonetia Papyrifera Leaves: Mechanisms and Potential Applications for Phosphate Removal. Environ. Sci. Pollut. Res. 2019, 26 (7), 6565-6575. https://doi.org/10.1007/s11356-01804095-w.

(84) Waqas, M.; Nizami, A. S.; Aburiazaiza, A. S.; Barakat, M. A.; Ismail, I. M. I.; Rashid, M. I. Optimization of Food Waste Compost with the Use of Biochar. J. Environ. Manage. 2018, 216, 70-81. https://doi.org/10.1016/J.JENVMAN.2017.06.015.

(85) Solaiman, Z. M.; Abbott, L. K.; Murphy, D. V. Biochar Phosphorus Concentration Dictates Mycorrhizal Colonisation, Plant Growth and Soil Phosphorus Cycling. Sci. Rep. 2019, 9 (1), 5062. https://doi.org/10.1038/s41598-019-41671-7.

(86) Panwar, N. L.; Pawar, A.; Salvi, B. L. Comprehensive Review on Production and Utilization of Biochar. SN Appl. Sci. 2019, 1 (2), 168. https://doi.org/10.1007/s42452-019-0172-6.

(87) Jiang, Z.; Lian, F.; Wang, Z.; Xing, B. The Role of Biochars in Sustainable Crop Production and Soil Resiliency. J. Exp. Bot. 2019, 71 (2), 520-542. https://doi.org/10.1093/jxb/erz301.

(88) Xiao, X.; Chen, B.; Chen, Z.; Zhu, L.; Schnoor, J. L. Insight into Multiple and Multilevel 
Structures of Biochars and Their Potential Environmental Applications: A Critical Review. Environ. Sci. Technol. 2018, 52 (9), 5027-5047. https://doi.org/10.1021/acs.est.7b06487.

(89) Liu, W.-J.; Jiang, H.; Yu, H.-Q. Development of Biochar-Based Functional Materials: Toward a Sustainable Platform Carbon Material. Chem. Rev. 2015, 115 (22), 12251-12285. https://doi.org/10.1021/acs.chemrev.5b00195.

(90) Billa, S. F.; Angwafo, T. E.; Ngome, A. F. Agro-Environmental Characterization of Biochar Issued from Crop Wastes in the Humid Forest Zone of Cameroon. Int. J. Recycl. Org. Waste Agric. 2019, 8 (1). https://doi.org/10.1007/s40093-018-0223-9.

(91) Gao, S.; DeLuca, T. H. Wood Biochar Impacts Soil Phosphorus Dynamics and Microbial Communities in Organically-Managed Croplands. Soil Biol. Biochem. 2018, 126, 144-150. https://doi.org/10.1016/J.SOILBIO.2018.09.002.

(92) Zhang, R.; Zhang, Y.; Song, L.; Song, X.; Hänninen, H.; Wu, J. Biochar Enhances Nut Quality of Torreya Grandis and Soil Fertility under Simulated Nitrogen Deposition. For. Ecol. Manage. 2017, 391, 321-329. https://doi.org/10.1016/J.FORECO.2017.02.036.

(93) Liu, Q.; Zhang, Y.; Liu, B.; Amonette, J. E.; Lin, Z.; Liu, G.; Ambus, P.; Xie, Z. How Does Biochar Influence Soil N Cycle? A Meta-Analysis. Plant Soil 2018, 426 (1-2), 211-225. https://doi.org/10.1007/s11104-018-3619-4.

(94) Joseph, U. E.; Toluwase, A. O.; Kehinde, E. O.; Omasan, E. E.; Tolulope, A. Y.; George, O. O.; Zhao, C.; Hongyan, W. Effect of Biochar on Soil Structure and Storage of Soil Organic Carbon and Nitrogen in the Aggregate Fractions of an Albic Soil. Arch. Agron. Soil Sci. 2019, 1-12. https://doi.org/10.1080/03650340.2019.1587412.

(95) Khademalrasoul, A.; Kuhn, N. J.; Elsgaard, L.; Hu, Y.; Iversen, B. V.; Heckrath, G. Short-Term Effects of Biochar Application on Soil Loss During a Rainfall-Runoff Simulation. Soil Sci. 2019, 184 (1), 17-24. https://doi.org/10.1097/SS.00000000000000247.

(96) Soinne, H.; Hovi, J.; Tammeorg, P.; Turtola, E. Effect of Biochar on Phosphorus Sorption and Clay Soil Aggregate Stability. Geoderma 2014, 219-220, 162-167. https://doi.org/10.1016/J.GEODERMA.2013.12.022.

(97) Lin, Y.; Munroe, P.; Joseph, S.; Kimber, S.; Van Zwieten, L. Nanoscale Organo-Mineral Reactions of Biochars in Ferrosol: An Investigation Using Microscopy. Plant Soil 2012, 357 (12), 369-380. https://doi.org/10.1007/s11104-012-1169-8.

(98) Jien, S.-H.; Wang, C.-S. Effects of Biochar on Soil Properties and Erosion Potential in a Highly Weathered Soil. CATENA 2013, 110, 225-233. https://doi.org/10.1016/J.CATENA.2013.06.021.

(99) Lee, S. S.; Shah, H. S.; Awad, Y. M.; Kumar, S.; Ok, Y. S. Synergy Effects of Biochar and Polyacrylamide on Plants Growth and Soil Erosion Control. Environ. Earth Sci. 2015, 74 (3), 2463-2473. https://doi.org/10.1007/s12665-015-4262-5.

(100) Inyang, M.; Dickenson, E. The Potential Role of Biochar in the Removal of Organic and Microbial Contaminants from Potable and Reuse Water: A Review. Chemosphere 2015, 134, 232-240.

(101) Shi, R.; Ni, N.; Nkoh, J. N.; Li, J.; Xu, R.; Qian, W. Beneficial Dual Role of Biochars in Inhibiting Soil Acidification Resulting from Nitrification. Chemosphere 2019.

(102) Wang, J.; Sun, N.; Xu, M.; Wang, S.; Zhang, J.; Cai, Z.; Cheng, Y. The Influence of Long-Term Animal Manure and Crop Residue Application on Abiotic and Biotic N Immobilization in an Acidified Agricultural Soil. Geoderma 2019, 337, 710-717. 
(103) Conyers, M. K.; Mullen, C. L.; Scott, B. J.; Poile, G. J.; Braysher, B. D. Long-Term Benefits of Limestone Applications to Soil Properties and to Cereal Crop Yields in Southern and Central New South Wales. Aust. J. Exp. Agric. 2003, 43 (1), 71-78.

(104) Guodao, Y. J. L. L. L. Research on Soil Acidification and Acidic Soil's Melioration [J]. J. South China Univ. Trop. Agric. 2006, 1.

(105) Zhang, H.; Dao, T. H.; Basta, N. T.; Dayton, E. A.; Daniel, T. C. Remediation Techniques for Manure Nutrient Loaded Soils. 2006.

(106) Palviainen, M.; Berninger, F.; Bruckman, V. J.; Köster, K.; de Assumpção, C. R. M.; Aaltonen, H.; Makita, N.; Mishra, A.; Kulmala, L.; Adamczyk, B.; Zhou, X.; Heinonsalo, J.; Köster, E.; Pumpanen, J. Effects of Biochar on Carbon and Nitrogen Fluxes in Boreal Forest Soil. Plant Soil 2018, 425 (1-2), 71-85. https://doi.org/10.1007/s11104-018-3568-y.

(107) Wu, D.; Senbayram, M.; Zang, H.; Ugurlar, F.; Aydemir, S.; Brüggemann, N.; Kuzyakov, Y.; Bol, R.; Blagodatskaya, E. Effect of Biochar Origin and Soil PH on Greenhouse Gas Emissions from Sandy and Clay Soils. Appl. Soil Ecol. 2018, 129, 121-127. https://doi.org/10.1016/J.APSOIL.2018.05.009.

(108) Si, L.; Xie, Y.; Ma, Q.; Wu, L. The Short-Term Effects of Rice Straw Biochar, Nitrogen and Phosphorus Fertilizer on Rice Yield and Soil Properties in a Cold Waterlogged Paddy Field. Sustainability 2018, 10 (2), 537. https://doi.org/10.3390/su10020537.

(109) Jeffery, S.; Verheijen, F. G. A.; van der Velde, M.; Bastos, A. C. A Quantitative Review of the Effects of Biochar Application to Soils on Crop Productivity Using Meta-Analysis. Agric. Ecosyst. Environ. 2011, 144 (1), 175-187.

(110) Verheijen, F.; Jeffery, S.; Bastos, A. C.; Van der Velde, M.; Diafas, I. Biochar Application to Soils. A Crit. Sci. Rev. Eff. soil Prop. Process. Funct. EUR 2010, 24099, 162.

(111) Xu, R.; Zhao, A.; Yuan, J.; Jiang, J. PH Buffering Capacity of Acid Soils from Tropical and Subtropical Regions of China as Influenced by Incorporation of Crop Straw Biochars. J. Soils Sediments 2012, 12 (4), 494-502.

(112) Novak, J. M.; Busscher, W. J.; Laird, D. L.; Ahmedna, M.; Watts, D. W.; Niandou, M. A. S. Impact of Biochar Amendment on Fertility of a Southeastern Coastal Plain Soil. Soil Sci. 2009, 174 (2), 105-112. https://doi.org/10.1097/SS.0b013e3181981d9a.

(113) Qian, L.; Chen, B. Dual Role of Biochars as Adsorbents for Aluminum: The Effects of OxygenContaining Organic Components and the Scattering of Silicate Particles. Environ. Sci. Technol. 2013, 47 (15), 8759-8768.

(114) Fidel, R. B.; Laird, D. A.; Thompson, M. L.; Lawrinenko, M. Characterization and Quantification of Biochar Alkalinity. Chemosphere 2017, 167, 367-373.

(115) Zhao, H.; Yu, L.; Yu, M.; Afzal, M.; Dai, Z.; Brookes, P.; Xu, J. Nitrogen Combined with Biochar Changed the Feedback Mechanism between Soil Nitrification and Cd Availability in an Acidic Soil. J. Hazard. Mater. 2019, 121631.

(116) Gondek, K.; Mierzwa-Hersztek, M.; Kopeć, M.; Sikora, J.; Głąb, T.; Szczurowska, K. Influence of Biochar Application on Reduced Acidification of Sandy Soil, Increased Cation Exchange Capacity, and the Content of Available Forms of K, Mg, and P. Polish J. Environ. Stud. 2019, 28 (1).

(117) Taghizadeh-Toosi, A.; Clough, T. J.; Sherlock, R. R.; Condron, L. M. Biochar Adsorbed Ammonia Is Bioavailable. Plant Soil 2012, 350 (1-2), 57-69. https://doi.org/10.1007/s11104-011- 
0870-3.

(118) Zhang, Y.; Chen, H.; Ji, G.; Zhang, Y.; Xiang, J.; Anwar, S.; Zhu, D. Effect of Rice-Straw Biochar Application on Rice (Oryza Sativa L.) Root Growth and Nitrogen Utilization in Acidified Paddy Soil. Int. J. Agric. Biol. 2018, 20 (11), 2529-2536.

(119) Shi, R.; Li, J.; Jiang, J.; Kamran, M. A.; Xu, R.; Qian, W. Incorporation of Corn Straw Biochar Inhibited the Re-Acidification of Four Acidic Soils Derived from Different Parent Materials. Environ. Sci. Pollut. Res. 2018, 25 (10), 9662-9672.

(120) Shi, R.; Hong, Z.; Li, J.; Jiang, J.; Kamran, M. A.; Xu, R.; Qian, W. Peanut Straw Biochar Increases the Resistance of Two Ultisols Derived from Different Parent Materials to Acidification: A Mechanism Study. J. Environ. Manage. 2018, 210, 171-179.

(121) Wang, J.; Zhang, B.; Tian, Y.; Zhang, H.; Cheng, Y.; Zhang, J. A Soil Management Strategy for Ameliorating Soil Acidification and Reducing Nitrification in Tea Plantations. Eur. J. Soil Biol. 2018, 88, 36-40.

(122) Mierzwa-Hersztek, M.; Gondek, K.; Klimkowicz-Pawlas, A.; Baran, A.; Bajda, T. Sewage Sludge Biochars Management-Ecotoxicity, Mobility of Heavy Metals, and Soil Microbial Biomass. Environ. Toxicol. Chem. 2018, 37 (4), 1197-1207.

(123) Cross, A.; Sohi, S. P. The Priming Potential of Biochar Products in Relation to Labile Carbon Contents and Soil Organic Matter Status. Soil Biol. Biochem. 2011, 43 (10), 2127-2134.

(124) Zimmerman, A. R.; Gao, B.; Ahn, M.-Y. Positive and Negative Carbon Mineralization Priming Effects among a Variety of Biochar-Amended Soils. Soil Biol. Biochem. 2011, 43 (6), 1169-1179.

(125) Zhao, S.; Ta, N.; Li, Z.; Yang, Y.; Zhang, X.; Liu, D.; Zhang, A.; Wang, X. Varying Pyrolysis Temperature Impacts Application Effects of Biochar on Soil Labile Organic Carbon and Humic Fractions. Appl. Soil Ecol. 2018, 123, 484-493. https://doi.org/https://doi.org/10.1016/j.apsoil.2017.09.007.

(126) Luo, Y.; Durenkamp, M.; De Nobili, M.; Lin, Q.; Brookes, P. C. Short Term Soil Priming Effects and the Mineralisation of Biochar Following Its Incorporation to Soils of Different PH. Soil Biol. Biochem. 2011, 43 (11), 2304-2314.

(127) Li, Y.; Zhou, C.; Qiu, Y.; Tigabu, M.; Ma, X. Effects of Biochar and Litter on Carbon and Nitrogen Mineralization and Soil Microbial Community Structure in a China Fir Plantation. J. For. Res. 2019, 30 (5), 1913-1923.

(128) Cui, J.; Ge, T.; Kuzyakov, Y.; Nie, M.; Fang, C.; Tang, B.; Zhou, C. Interactions between Biochar and Litter Priming: A Three-Source $14 C$ and $\Delta 13 C$ Partitioning Study. Soil Biol. Biochem. 2017, 104, 49-58.

(129) Maestrini, B.; Herrmann, A. M.; Nannipieri, P.; Schmidt, M. W. I.; Abiven, S. Ryegrass-Derived Pyrogenic Organic Matter Changes Organic Carbon and Nitrogen Mineralization in a Temperate Forest Soil. Soil Biol. Biochem. 2014, 69, 291-301.

(130) Ventura, M.; Alberti, G.; Panzacchi, P.; Delle Vedove, G.; Miglietta, F.; Tonon, G. Biochar Mineralization and Priming Effect in a Poplar Short Rotation Coppice from a 3-Year Field Experiment. Biol. Fertil. soils 2019, 55 (1), 67-78.

(131) Kuzyakov, Y.; Friedel, J. K.; Stahr, K. Review of Mechanisms and Quantification of Priming Effects. Soil Biol. Biochem. 2000, 32 (11-12), 1485-1498.

(132) Figueiredo, C. C. de; Farias, W. M.; Melo, B. A. de; Chagas, J. K. M.; Vale, A. T.; Coser, T. R. Labile and Stable Pools of Organic Matter in Soil Amended with Sewage Sludge Biochar. Arch. 
Agron. Soil Sci. 2019, 65 (6), 770-781.

(133) Ji, X.; Abakumov, E.; Xie, X.; Wei, D.; Tang, R.; Ding, J.; Cheng, Y.; Chen, J. Preferential Alternatives to Returning All Crop Residues as Biochar to the Crop Field? A Three-Source 13C and 14C Partitioning Study. J. Agric. Food Chem. 2019, 67 (41), 11322-11330.

(134) Bista, P.; Ghimire, R.; Machado, S.; Pritchett, L. Biochar Effects on Soil Properties and Wheat Biomass Vary with Fertility Management. Agronomy . 2019. https://doi.org/10.3390/agronomy9100623.

(135) Schofield, H. K.; Pettitt, T. R.; Tappin, A. D.; Rollinson, G. K.; Fitzsimons, M. F. Biochar Incorporation Increased Nitrogen and Carbon Retention in a Waste-Derived Soil. Sci. Total Environ. 2019, 690, 1228-1236.

(136) Andrés, P.; Rosell-Melé, A.; Colomer-Ventura, F.; Denef, K.; Cotrufo, M. F.; Riba, M.; Alcañiz, J. M. Belowground Biota Responses to Maize Biochar Addition to the Soil of a Mediterranean Vineyard. Sci. Total Environ. 2019, 660, 1522-1532. https://doi.org/10.1016/J.SCITOTENV.2019.01.101.

(137) Orlova, N.; Abakumov, E.; Orlova, E.; Yakkonen, K.; Shahnazarova, V. Soil Organic Matter Alteration under Biochar Amendment: Study in the Incubation Experiment on the Podzol Soils of the Leningrad Region (Russia). J. Soils Sediments 2019, 19 (6), 2708-2716.

(138) Kammoun-Rigane, M.; Hlel, H.; Medhioub, K. Biochars Induced Changes in the Physicochemical Characteristics of Technosols: Effects of Feedstock and Pyrolysis Temperature. In Recent Advances in Geo-Environmental Engineering, Geomechanics and Geotechnics, and Geohazards; Springer, 2019; pp 109-111.

(139) Raiesi, F.; Khadem, A. Short-Term Effects of Maize Residue Biochar on Kinetic and Thermodynamic Parameters of Soil $\beta$-Glucosidase. Biochar 2019, 1 (2), 213-227. https://doi.org/10.1007/s42773-019-00016-3.

(140) Lehman, R.; Cambardella, C.; Stott, D.; Acosta-Martinez, V.; Manter, D.; Buyer, J.; Maul, J.; Smith, J.; Collins, H.; Halvorson, J.; Kremer, R.; Lundgren, J.; Ducey, T.; Jin, V.; Karlen, D. Understanding and Enhancing Soil Biological Health: The Solution for Reversing Soil Degradation. Sustainability 2015, 7 (1), 988-1027. https://doi.org/10.3390/su7010988.

(141) Morrow, J. G.; Huggins, D. R.; Carpenter-Boggs, L. A.; Reganold, J. P. Evaluating Measures to Assess Soil Health in Long-Term Agroecosystem Trials. Soil Sci. Soc. Am. J. 2016, 80 (2), 450. https://doi.org/10.2136/sssaj2015.08.0308.

(142) Muhammad, N.; Dai, Z.; Xiao, K.; Meng, J.; Brookes, P. C.; Liu, X.; Wang, H.; Wu, J.; Xu, J. Changes in Microbial Community Structure Due to Biochars Generated from Different Feedstocks and Their Relationships with Soil Chemical Properties. Geoderma 2014, 226-227, 270-278. https://doi.org/10.1016/J.GEODERMA.2014.01.023.

(143) Wang, D.; Zhang, N.; Tang, H.; Adams, J. M.; Sun, B.; Liang, Y. Straw Biochar Strengthens the Life Strategies and Network of Rhizosphere Fungi in Manure Fertilized Soils. Soil Ecol. Lett. 2019, 1 (1-2), 72-84. https://doi.org/10.1007/s42832-019-0008-8.

(144) Zhang, L.; Jing, Y.; Xiang, Y.; Zhang, R.; Lu, H. Responses of Soil Microbial Community Structure Changes and Activities to Biochar Addition: A Meta-Analysis. Sci. Total Environ. 2018, 643, 926-935. https://doi.org/10.1016/J.SCITOTENV.2018.06.231.

(145) Palansooriya, K. N.; Wong, J. T. F.; Hashimoto, Y.; Huang, L.; Rinklebe, J.; Chang, S. X.; Bolan, N.; Wang, H.; Ok, Y. S. Response of Microbial Communities to Biochar-Amended Soils: A 
Critical Review. Biochar 2019, 1 (1), 3-22. https://doi.org/10.1007/s42773-019-00009-2.

(146) Song, D.; Xi, X.; Zheng, Q.; Liang, G.; Zhou, W.; Wang, X. Soil Nutrient and Microbial Activity Responses to Two Years after Maize Straw Biochar Application in a Calcareous Soil. Ecotoxicol. Environ. Saf. 2019, 180, 348-356. https://doi.org/10.1016/J.ECOENV.2019.04.073.

(147) Chen, J.; Sun, X.; Zheng, J.; Zhang, X.; Liu, X.; Bian, R.; Li, L.; Cheng, K.; Zheng, J.; Pan, G. Biochar Amendment Changes Temperature Sensitivity of Soil Respiration and Composition of Microbial Communities 3 Years after Incorporation in an Organic Carbon-Poor Dry Cropland Soil. Biol. Fertil. Soils 2018, 54 (2), 175-188. https://doi.org/10.1007/s00374-017-12536.

(148) Liu, Z.; Zhu, M.; Wang, J.; Liu, X.; Guo, W.; Zheng, J.; Bian, R.; Wang, G.; Zhang, X.; Cheng, K.; Liu, X.; Li, L.; Pan, G. The Responses of Soil Organic Carbon Mineralization and Microbial Communities to Fresh and Aged Biochar Soil Amendments. GCB Bioenergy 2019, 11 (12), 14081420. https://doi.org/10.1111/gcbb.12644.

(149) Luo, Y.; Dungait, J. A. J.; Zhao, X.; Brookes, P. C.; Durenkamp, M.; Li, G.; Lin, Q. Pyrolysis Temperature during Biochar Production Alters Its Subsequent Utilization by Microorganisms in an Acid Arable Soil. L. Degrad. Dev. 2018, 29 (7), 2183-2188. https://doi.org/10.1002/ldr.2846.

(150) Du, Y.; Wu, J.; Anane, P.-S.; Wu, Y.; Wang, C.; Liu, S. Effects of Different Biochars on Physicochemical Properties and Fungal Communities of Black Soil. Polish J. Environ. Stud. 2019, 28 (5), 3125-3132. https://doi.org/10.15244/pjoes/94816.

(151) Bonanomi, G.; Ippolito, F.; Cesarano, G.; Vinale, F.; Lombardi, N.; Crasto, A.; Woo, S. L.; Scala, F. Biochar Chemistry Defined by 13C-CPMAS NMR Explains Opposite Effects on Soilborne Microbes and Crop Plants. Appl. Soil Ecol. 2018, 124, 351-361. https://doi.org/10.1016/J.APSOIL.2017.11.027.

(152) Zhang, Y.; Liu, Y.; Zhang, G.; Guo, X.; Sun, Z.; Li, T. The Effects of Rice Straw and Biochar Applications on the Microbial Community in a Soil with a History of Continuous Tomato Planting History. Agronomy 2018, 8 (5), 65. https://doi.org/10.3390/agronomy8050065.

(153) Paymaneh, Z.; Gryndler, M.; Konvalinková, T.; Benada, O.; Borovička, J.; Bukovská, P.; Püschel, D.; Řezáčová, V.; Sarcheshmehpour, M.; Jansa, J. Soil Matrix Determines the Outcome of Interaction Between Mycorrhizal Symbiosis and Biochar for Andropogon Gerardii Growth and Nutrition. Front. Microbiol. 2018, 9, 2862. https://doi.org/10.3389/fmicb.2018.02862.

(154) Dangi, S.; Gao, S.; Duan, Y.; Wang, D. Soil Microbial Community Structure Affected by Biochar and Fertilizer Sources. Appl. Soil Ecol. 2019. https://doi.org/10.1016/j.apsoil.2019.103452.

(155) Li, Y.; Yang, Y.; Shen, F.; Tian, D.; Zeng, Y.; Yang, G.; Zhang, Y.; Deng, S. Partitioning Biochar Properties to Elucidate Their Contributions to Bacterial and Fungal Community Composition of Purple Soil. Sci. Total Environ. 2019, 648, 1333-1341. https://doi.org/10.1016/J.SCITOTENV.2018.08.222.

(156) Zheng, N.; Yu, Y.; Shi, W.; Yao, H. Biochar Suppresses N2O Emissions and Alters Microbial Communities in an Acidic Tea Soil. Environ. Sci. Pollut. Res. 2019, 1-10. https://doi.org/10.1007/s11356-019-06704-8.

(157) Dai, Z.; Enders, A.; Rodrigues, J. L. M.; Hanley, K. L.; Brookes, P. C.; Xu, J.; Lehmann, J. Soil Fungal Taxonomic and Functional Community Composition as Affected by Biochar Properties. Soil Biol. Biochem. 2018, 126, 159-167. https://doi.org/10.1016/J.SOILBIO.2018.09.001. 
(158) Nie, C.; Yang, X.; Niazi, N. K.; Xu, X.; Wen, Y.; Rinklebe, J.; Ok, Y. S.; Xu, S.; Wang, H. Impact of Sugarcane Bagasse-Derived Biochar on Heavy Metal Availability and Microbial Activity: A Field Study. Chemosphere 2018, 200, 284-282. https://doi.org/10.1016/J.CHEMOSPHERE.2018.02.134.

(159) Liu, Y.; Zhu, J.; Ye, C.; Zhu, P.; Ba, Q.; Pang, J.; Shu, L. Effects of Biochar Application on the Abundance and Community Composition of Denitrifying Bacteria in a Reclaimed Soil from Coal Mining Subsidence Area. Sci. Total Environ. 2018, 625, 1218-1224. https://doi.org/10.1016/J.SCITOTENV.2018.01.003.

(160) Yu, J.; Deem, L. M.; Crow, S. E.; Deenik, J. L.; Penton, C. R. Biochar Application Influences Microbial Assemblage Complexity and Composition Due to Soil and Bioenergy Crop Type Interactions. Soil Biol. Biochem. 2018, 117, 97-107. https://doi.org/10.1016/J.SOILBIO.2017.11.017.

(161) Liu, X.; Li, J.; Yu, L.; Pan, H.; Liu, H.; Liu, Y.; Di, H.; Li, Y.; Xu, J. Simultaneous Measurement of Bacterial Abundance and Composition in Response to Biochar in Soybean Field Soil Using 16S RRNA Gene Sequencing. L. Degrad. Dev. 2018, 29 (7), 2172-2182. https://doi.org/10.1002/ldr.2838.

(162) Liu, X.; Zhou, J.; Chi, Z.; Zheng, J.; Li, L.; Zhang, X.; Zheng, J.; Cheng, K.; Bian, R.; Pan, G. Biochar Provided Limited Benefits for Rice Yield and Greenhouse Gas Mitigation Six Years Following an Amendment in a Fertile Rice Paddy. CATENA 2019, 179, $20-28$. https://doi.org/10.1016/J.CATENA.2019.03.033.

(163) Nguyen, T. T. N.; Wallace, H. M.; Xu, C.-Y.; (Van) Zwieten, L.; Weng, Z. H.; Xu, Z.; Che, R.; Tahmasbian, I.; Hu, H.-W.; Bai, S. H. The Effects of Short Term, Long Term and Reapplication of Biochar on Soil Bacteria. Sci. Total Environ. 2018, 636, 142-151. https://doi.org/10.1016/J.SCITOTENV.2018.04.278.

(164) Cole, E. J.; Zandvakili, O. R.; Blanchard, J.; Xing, B.; Hashemi, M.; Etemadi, F. Investigating Responses of Soil Bacterial Community Composition to Hardwood Biochar Amendment Using High-Throughput PCR Sequencing. Appl. Soil Ecol. 2019, 136, 80-85. https://doi.org/10.1016/J.APSOIL.2018.12.010.

(165) Song, Y.; Li, X.; Xu, M.; Jiao, W.; Bian, Y.; Yang, X.; Gu, C.; Wang, F.; Jiang, X. Does Biochar Induce Similar Successions of Microbial Community Structures Among Different Soils? Bull. Environ. Contam. Toxicol. 2019, 103 (4), 642-650. https://doi.org/10.1007/s00128-019-02687-x.

(166) Ge, X.; Cao, Y.; Zhou, B.; Wang, X.; Yang, Z.; Li, M.-H. Biochar Addition Increases Subsurface Soil Microbial Biomass but Has Limited Effects on Soil CO2 Emissions in Subtropical Moso Bamboo Plantations. Appl. Soil Ecol. 2019, 142, 155-165. https://doi.org/10.1016/J.APSOIL.2019.04.021.

(167) Han Weng, Z.; Van Zwieten, L.; Singh, B. P.; Tavakkoli, E.; Joseph, S.; Macdonald, L. M.; Rose, T. J.; Rose, M. T.; Kimber, S. W. L.; Morris, S.; Cozzolino, D.; Araujo, J. R.; Archanjo, B. S.; Cowie, A. Biochar Built Soil Carbon over a Decade by Stabilizing Rhizodeposits. Nat. Clim. Chang. 2017, 7 (5), 371-376. https://doi.org/10.1038/nclimate3276.

(168) Brändli, R. C.; Hartnik, T.; Henriksen, T.; Cornelissen, G. Sorption of Native Polyaromatic Hydrocarbons (PAH) to Black Carbon and Amended Activated Carbon in Soil. Chemosphere 2008, 73 (11), 1805-1810.

(169) Jonker, M. T. O.; van der Heijden, S. A.; Kreitinger, J. P.; Hawthorne, S. B. Predicting PAH 
Bioaccumulation and Toxicity in Earthworms Exposed to Manufactured Gas Plant Soils with Solid-Phase Microextraction. Environ. Sci. Technol. 2007, 41 (21), 7472-7478.

(170) Kreitinger, J. P.; Quĩones-Rivera, A.; Neuhauser, E. F.; Alexander, M.; Hawthorne, S. B. Supercritical Carbon Dioxide Extraction as a Predictor of Polycyclic Aromatic Hydrocarbon Bioaccumulation and Toxicity by Earthworms in Manufactured-gas Plant Site Soils. Environ. Toxicol. Chem. An Int. J. 2007, 26 (9), 1809-1817.

(171) O'Connor, D.; Peng, T.; Zhang, J.; Tsang, D. C. W.; Alessi, D. S.; Shen, Z.; Bolan, N. S.; Hou, D. Biochar Application for the Remediation of Heavy Metal Polluted Land: A Review of in Situ Field Trials. Sci. Total Environ. 2018, 619, 815-826.

(172) He, L.; Zhong, H.; Liu, G.; Dai, Z.; Brookes, P. C.; Xu, J. Remediation of Heavy Metal Contaminated Soils by Biochar: Mechanisms, Potential Risks and Applications in China. Environ. Pollut. 2019.

(173) Beesley, L.; Moreno-Jiménez, E.; Gomez-Eyles, J. L. Effects of Biochar and Greenwaste Compost Amendments on Mobility, Bioavailability and Toxicity of Inorganic and Organic Contaminants in a Multi-Element Polluted Soil. Environ. Pollut. 2010, 158 (6), 2282-2287. https://doi.org/https://doi.org/10.1016/j.envpol.2010.02.003.

(174) Cui, L.; Pan, G.; Li, L.; Bian, R.; Liu, X.; Yan, J.; Quan, G.; Ding, C.; Chen, T.; Liu, Y. Continuous Immobilization of Cadmium and Lead in Biochar Amended Contaminated Paddy Soil: A Five-Year Field Experiment. Ecol. Eng. 2016, 93, 1-8.

(175) Lomaglio, T.; Hattab-Hambli, N.; Miard, F.; Lebrun, M.; Nandillon, R.; Trupiano, D.; Scippa, G. S.; Gauthier, A.; Motelica-Heino, M.; Bourgerie, S. Cd, Pb, and Zn Mobility and (Bio) Availability in Contaminated Soils from a Former Smelting Site Amended with Biochar. Environ. Sci. Pollut. Res. 2018, 25 (26), 25744-25756.

(176) Figueiredo, C. C. de; Chagas, J. K. M.; da Silva, J.; Paz-Ferreiro, J. Short-Term Effects of a Sewage Sludge Biochar Amendment on Total and Available Heavy Metal Content of a Tropical Soil. Geoderma 2019, 344, 39. https://doi.org/https://doi.org/10.1016/j.geoderma.2019.01.052.

(177) Nzediegwu, C.; Prasher, S.; Elsayed, E.; Dhiman, J.; Mawof, A.; Patel, R. Effect of Biochar on Heavy Metal Accumulation in Potatoes from Wastewater Irrigation. J. Environ. Manage. 2019, 232, 153-164. https://doi.org/https://doi.org/10.1016/j.jenvman.2018.11.013.

(178) Wang, Y.; Zhong, B.; Shafi, M.; Ma, J.; Guo, J.; Wu, J.; Ye, Z.; Liu, D.; Jin, H. Effects of Biochar on Growth, and Heavy Metals Accumulation of Moso Bamboo (Phyllostachy Pubescens), Soil Physical Properties, and Heavy Metals Solubility in Soil. Chemosphere 2019, 219, 510-516.

(179) Kamran, M.; Malik, Z.; Parveen, A.; Huang, L.; Riaz, M.; Bashir, S.; Mustafa, A.; Abbasi, G. H.; Xue, B.; Ali, U. Ameliorative Effects of Biochar on Rapeseed (Brassica Napus L.) Growth and Heavy Metal Immobilization in Soil Irrigated with Untreated Wastewater. J. Plant Growth Regul. 2019, 1-16.

(180) Ghori, S. A.; Gul, S.; Tahir, S.; Sohail, M.; Batool, S.; Shahwani, M. N.; Bano, G. Wood-Derived Biochar Influences Nutrient Use Efficiency of Heavy Metals in Spinach (Spinacia Oleracea) under Groundwater and Wastewater Irrigation. J. Environ. Eng. Landsc. Manag. 2019, 27 (3), 144-152.

(181) Antonangelo, J. A.; Zhang, H. Heavy Metal Phytoavailability in a Contaminated Soil of Northeastern Oklahoma as Affected by Biochar Amendment. Environ. Sci. Pollut. Res. 2019, 26 
(32), 33582-33593.

(182) Cui, L.; Noerpel, M. R.; Scheckel, K. G.; Ippolito, J. A. Wheat Straw Biochar Reduces Environmental Cadmium Bioavailability. Environ. Int. 2019, 126, 69-75.

(183) Shen, Z.; Zhang, J.; Hou, D.; Tsang, D. C. W.; Ok, Y. S.; Alessi, D. S. Synthesis of MgO-Coated Corncob Biochar and Its Application in Lead Stabilization in a Soil Washing Residue. Environ. Int. 2019, 122, 357-362.

(184) Qian, T.-T.; Wu, P.; Qin, Q.-Y.; Huang, Y.-N.; Wang, Y.-J.; Zhou, D.-M. Screening of Wheat Straw Biochars for the Remediation of Soils Polluted with Zn (II) and Cd (II). J. Hazard. Mater. 2019, 362, 311-317.

(185) Novak, J. M.; Ippolito, J. A.; Watts, D. W.; Sigua, G. C.; Ducey, T. F.; Johnson, M. G. Biochar Compost Blends Facilitate Switchgrass Growth in Mine Soils by Reducing $\mathrm{Cd}$ and $\mathrm{Zn}$ Bioavailability. Biochar 2019, 1 (1), 97-114.

(186) Derakhshan-Nejad, Z; Jung, M. C. Remediation of Multi-Metal Contaminated Soil Using Biochars from Rice Husk and Maple Leaves. J. Mater. Cycles Waste Manag. 2019, 21 (3), 457468.

(187) Andrey, G.; Rajput, V.; Tatiana, M.; Saglara, M.; Svetlana, S.; Igor, K.; Grigoryeva, T. V; Vasily, C.; Iraida, A.; Vladislav, Z. The Role of Biochar-Microbe Interaction in Alleviating Heavy Metal Toxicity in Hordeum Vulgare L. Grown in Highly Polluted Soils. Appl. geochemistry 2019, 104, 93-101.

(188) Schaeffer, S.; Koepke, T.; Dhingra, A. Tobacco: A Model Plant for Understanding the Mechanism of Abiotic Stress Tolerance. In Improving Crop Resistance to Abiotic Stress; WileyVCH Verlag GmbH \& Co. KGaA: Weinheim, Germany, 2012; Vol. 2, pp 1169-1201. https://doi.org/10.1002/9783527632930.ch46.

(189) Dahlawi, S.; Naeem, A.; Rengel, Z.; Naidu, R. Biochar Application for the Remediation of SaltAffected Soils: Challenges and Opportunities. Sci. Total Environ. 2018, 625, 320-335.

(190) Lashari, M. S.; Liu, Y.; Li, L.; Pan, W.; Fu, J.; Pan, G.; Zheng, J.; Zheng, J.; Zhang, X.; Yu, X. Effects of Amendment of Biochar-Manure Compost in Conjunction with Pyroligneous Solution on Soil Quality and Wheat Yield of a Salt-Stressed Cropland from Central China Great Plain. F. Crop. Res. 2013, 144, 113-118.

(191) Akhtar, S. S.; Andersen, M. N.; Liu, F. Biochar Mitigates Salinity Stress in Potato. J. Agron. Crop Sci. 2015, 201 (5), 368-378.

(192) Akhtar, S. S.; Andersen, M. N.; Liu, F. Residual Effects of Biochar on Improving Growth, Physiology and Yield of Wheat under Salt Stress. Agric. Water Manag. 2015, 158, 61-68.

(193) Akhtar, S. S.; Andersen, M. N.; Naveed, M.; Zahir, Z. A.; Liu, F. Interactive Effect of Biochar and Plant Growth-Promoting Bacterial Endophytes on Ameliorating Salinity Stress in Maize. Funct. Plant Biol. 2015, 42 (8), 770-781.

(194) Lashari, M. S.; Ye, Y.; Ji, H.; Li, L.; Kibue, G. W.; Lu, H.; Zheng, J.; Pan, G. Biochar-Manure Compost in Conjunction with Pyroligneous Solution Alleviated Salt Stress and Improved Leaf Bioactivity of Maize in a Saline Soil from Central China: A 2-year Field Experiment. J. Sci. Food Agric. 2015, 95 (6), 1321-1327.

(195) Zhang, J.; Bai, Z.; Huang, J.; Hussain, S.; Zhao, F.; Zhu, C.; Zhu, L.; Cao, X.; Jin, Q. Biochar Alleviated the Salt Stress of Induced Saline Paddy Soil and Improved the Biochemical Characteristics of Rice Seedlings Differing in Salt Tolerance. Soil Tillage Res. 2019, 195, 104372. 
https://doi.org/https://doi.org/10.1016/j.still.2019.104372.

(196) Abd El-Mageed, T. A.; Rady, M. M.; Taha, R. S.; Abd El Azeam, S.; Simpson, C. R.; Semida, W. M. Effects of Integrated Use of Residual Sulfur-Enhanced Biochar with Effective Microorganisms on Soil Properties, Plant Growth and Short-Term Productivity of Capsicum Annuum under Salt Stress. Sci. Hortic. (Amsterdam). 2020, 261, 108930. https://doi.org/https://doi.org/10.1016/j.scienta.2019.108930.

(197) Mingyi, H.; Zhang, Z.; Zhu, C.; Zhai, Y.; Peirong, L. Effect of Biochar on Sweet Corn and Soil Salinity under Conjunctive Irrigation with Brackish Water in Coastal Saline Soil. Sci. Hortic. (Amsterdam). 2019, 250, 405-413. https://doi.org/10.1016/j.scienta.2019.02.077.

(198) Hafeez, F.; Rizwan, M.; Saqib, M.; Yasmeen, T.; Ali, S.; Abbas, T.; Zia-ur-Rehman, M.; Qayyum, M. Residual Effect of Biochar on Growth, Antioxidant Defence and Cadmium (Cd) Accumulation in Rice in a Cd Contaminated Saline Soil. Pakistan J. Agric. Sci. 2018, 56. https://doi.org/10.21162/PAKJAS/19.7546.

(199) Nikpour-Rashidabad, N.; Tavasolee, A.; Torabian, S.; Farhangi-Abriz, S. The Effect of Biochar on the Physiological, Morphological and Anatomical Characteristics of Mung Bean Roots after Exposure to Salt Stress. Arch. Biol. Sci. 2019, 71, 14. https://doi.org/10.2298/ABS181005014N.

(200) Aboshanab, W.; Osman, M.; Nessim, A.; Mohsen, A.; elsaka, M. Evaluation of Biochar as a Soil Amendment for Alleviating the Harmful Effect of Salinity on Vigna Unguiculata (L.) Walp. 2019.

(201) Jaiswal, A. K.; Frenkel, O.; Tsechansky, L.; Elad, Y.; Graber, E. R. Immobilization and Deactivation of Pathogenic Enzymes and Toxic Metabolites by Biochar: A Possible Mechanism Involved in Soilborne Disease Suppression. Soil Biol. Biochem. 2018, 121, 59-66.

(202) Harel, Y. M.; Elad, Y.; Rav-David, D.; Borenstein, M.; Shulchani, R.; Lew, B.; Graber, E. R. Biochar Mediates Systemic Response of Strawberry to Foliar Fungal Pathogens. Plant Soil 2012, 357 (1-2), 245-257.

(203) Kumar, A.; Elad, Y.; Tsechansky, L.; Abrol, V.; Lew, B.; Offenbach, R.; Graber, E. R. Biochar Potential in Intensive Cultivation of Capsicum Annuum L.(Sweet Pepper): Crop Yield and Plant Protection. J. Sci. Food Agric. 2018, 98 (2), 495-503.

(204) Jaiswal, A. K.; Elad, Y.; Paudel, I.; Graber, E. R.; Cytryn, E.; Frenkel, O. Linking the Belowground Microbial Composition, Diversity and Activity to Soilborne Disease Suppression and Growth Promotion of Tomato Amended with Biochar. Sci. Rep. 2017, 7 (1), 44382. https://doi.org/10.1038/srep44382.

(205) Knox, O. G. G.; Oghoro, C. O.; Burnett, F. J.; Fountaine, J. M. Biochar Increases Soil PH, but Is as Ineffective as Liming at Controlling Clubroot. J. Plant Pathol. 2015, 149-152.

(206) Bonanomi, G.; Ippolito, F.; Scala, F. A" Black" Future for Plant Pathology? Biochar as a New Soil Amendment for Controlling Plant Diseases. J. Plant Pathol. 2015, 97 (2).

(207) Jaiswal, A. K.; Graber, E. R.; Elad, Y.; Frenkel, O. Biochar as a Management Tool for Soilborne Diseases Affecting Early Stage Nursery Seedling Production. Crop Prot. 2019, 120, $34-42$.

(208) Lechenet, M.; Dessaint, F.; Py, G.; Makowski, D.; Munier-Jolain, N. Reducing Pesticide Use While Preserving Crop Productivity and Profitability on Arable Farms. Nat. Plants 2017, 3 (3), 17008. https://doi.org/10.1038/nplants.2017.8.

(209) Elijah, O.; Rahman, T. A.; Orikumhi, I.; Leow, C. Y.; Hindia, M. H. D. N. An Overview of Internet of Things (IoT) and Data Analytics in Agriculture: Benefits and Challenges. IEEE 
Internet Things J. 2018, 5 (5), 3758-3773. https://doi.org/10.1109/JIOT.2018.2844296.

(210) Prost, L.; Berthet, E. T. A.; Cerf, M.; Jeuffroy, M.-H.; Labatut, J.; Meynard, J.-M. Innovative Design for Agriculture in the Move towards Sustainability: Scientific Challenges. Res. Eng. Des. 2017, 28 (1), 119-129. https://doi.org/10.1007/s00163-016-0233-4.

(211) Reganold, J. P.; Wachter, J. M. Organic Agriculture in the Twenty-First Century. Nat. Plants 2016, 2 (2), 15221. https://doi.org/10.1038/nplants.2015.221.

(212) Kravchenko, A. N.; Snapp, S. S.; Robertson, G. P. Field-Scale Experiments Reveal Persistent Yield Gaps in Low-Input and Organic Cropping Systems. Proc. Natl. Acad. Sci. U. S. A. 2017, 114 (5), 926-931. https://doi.org/10.1073/pnas.1612311114.

(213) De Ponti, T.; Rijk, B.; Van Ittersum, M. K. The Crop Yield Gap between Organic and Conventional Agriculture. Agric. Syst. 2012, 108, 1-9. https://doi.org/10.1016/j.agsy.2011.12.004.

(214) Sharpe, R. M.; Gustafson, L.; Hewitt, S.; Kilian, B.; Crabb, J.; Hendrickson, C.; Jiwan, D.; Andrews, P.; Dhingra, A. Concomitant Phytonutrient and Transcriptome Analysis of Mature Fruit and Leaf Tissues of Tomato (Solanum Lycopersicum L. Cv. Oregon Spring) Grown Using Organic and Conventional Fertilizer. PLoS One 2020, 15 (1), e0227429. https://doi.org/10.1371/journal.pone.0227429.

(215) Zheng, H.; Wang, X.; Chen, L.; Wang, Z.; Xia, Y.; Zhang, Y.; Wang, H.; Luo, X.; Xing, B. Enhanced Growth of Halophyte Plants in Biochar-Amended Coastal Soil: Roles of Nutrient Availability and Rhizosphere Microbial Modulation. Plant. Cell Environ. 2018, 41 (3), 517-532. https://doi.org/10.1111/pce.12944.

(216) Laird, D. A.; Novak, J. M.; Collins, H. P.; Ippolito, J. A.; Karlen, D. L.; Lentz, R. D.; Sistani, K. R.; Spokas, K.; Van Pelt, R. S. Multi-Year and Multi-Location Soil Quality and Crop Biomass Yield Responses to Hardwood Fast Pyrolysis Biochar. Geoderma 2017, 289, 46-53. https://doi.org/10.1016/j.geoderma.2016.11.025.

(217) Knapp, S.; van der Heijden, M. G. A. A Global Meta-Analysis of Yield Stability in Organic and Conservation Agriculture. Nat. Commun. 2018, 9 (1), 1-9. https://doi.org/10.1038/s41467-01805956-1.

(218) Biederman, L. A.; Harpole, W. S. Biochar and Its Effects on Plant Productivity and Nutrient Cycling: A Meta-Analysis. GCB Bioenergy 2013, $5 \quad$ (2), 202-214. https://doi.org/10.1111/gcbb.12037.

(219) Amoakwah, E.; Arthur, E.; Frimpong, K. A.; Parikh, S. J.; Islam, R. Soil Organic Carbon Storage and Quality Are Impacted by Corn Cob Biochar Application on a Tropical Sandy Loam. J. Soils Sediments 2020, 20 (4), 1960-1969. https://doi.org/10.1007/s11368-019-02547-5.

(220) Fryda, L.; Visser, R.; Schmidt, J. BIOCHAR REPLACES PEAT IN HORTICULTURE: ENVIRONMENTAL IMPACT ASSESSMENT OF COMBINED BIOCHAR \& BIOENERGY PRODUCTION. Detritus 2018 - Vol. 2019, No. 5, 0. https://doi.org/10.31025/26114135/2019.13778.

(221) Woldetsadik, D.; Drechsel, P.; Marschner, B.; Itanna, F.; Gebrekidan, H. Effect of Biochar Derived from Faecal Matter on Yield and Nutrient Content of Lettuce (Lactuca Sativa) in Two Contrasting Soils. Environ. Syst. Res. 2018, 6 (1), 2. https://doi.org/10.1186/s40068-017-0082-9.

(222) Boersma, M.; Wrobel-Tobiszewska, A.; Murphy, L.; Eyles, A. Impact of Biochar Application on the Productivity of a Temperate Vegetable Cropping System. New Zeal. J. Crop Hortic. Sci. 
2017, 45 (4), 277-288. https://doi.org/10.1080/01140671.2017.1329745.

(223) Thi Thu Hien, T.; Shinogi, Y.; Taniguchi, T.; Hien, T. T. T.; Shinogi, Y.; Taniguchi, T. The Different Expressions of Draft Cherry Tomato Growth, Yield, Quality under Bamboo and Rice Husk Biochars Application to Clay Loamy Soil. Agric. Sci. 2017, 08 (09), 934-948. https://doi.org/10.4236/as.2017.89068.

(224) Nzediegwu, C.; Prasher, S.; Elsayed, E.; Dhiman, J.; Mawof, A.; Patel, R. Effect of Biochar on the Yield of Potatoes Cultivated Under Wastewater Irrigation for Two Seasons. J. Soil Sci. Plant Nutr. 2019, 19 (4), 865-877. https://doi.org/10.1007/s42729-019-00085-0.

(225) Griffin, D. E.; Wang, D.; Parikh, S. J.; Scow, K. M. Short-Lived Effects of Walnut Shell Biochar on Soils and Crop Yields in a Long-Term Field Experiment. Agric. Ecosyst. Environ. 2017, 236, 21-29. https://doi.org/10.1016/J.AGEE.2016.11.002.

(226) Li, S.; Shangguan, Z. Positive Effects of Apple Branch Biochar on Wheat Yield Only Appear at a Low Application Rate, Regardless of Nitrogen and Water Conditions. J. Soils Sediments 2018, 18 (11), 3235-3243. https://doi.org/10.1007/s11368-018-1994-3.

(227) Faloye, O. T.; Alatise, M. O.; Ajayi, A. E.; Ewulo, B. S. Effects of Biochar and Inorganic Fertiliser Applications on Growth, Yield and Water Use Efficiency of Maize under Deficit Irrigation. Agric. Water Manag. 2019, 217, 165-178. https://doi.org/10.1016/j.agwat.2019.02.044.

(228) Kang, S.-W.; Kim, S.-H.; Park, J.-H.; Seo, D.-C.; Ok, Y. S.; Cho, J.-S. Effect of Biochar Derived from Barley Straw on Soil Physicochemical Properties, Crop Growth, and Nitrous Oxide Emission in an Upland Field in South Korea. Environ. Sci. Pollut. Res. 2018, 25 (26), 2581325821. https://doi.org/10.1007/s11356-018-1888-3.

(229) Liu, B.; Cai, Z.; Zhang, Y.; Liu, G.; Luo, X.; Zheng, H. Comparison of Efficacies of Peanut Shell Biochar and Biochar-Based Compost on Two Leafy Vegetable Productivity in an Infertile Land. Chemosphere 2019, 224, 151-161. https://doi.org/10.1016/J.CHEMOSPHERE.2019.02.100.

(230) Alotaibi, K. D.; Schoenau, J. J. Addition of Biochar to a Sandy Desert Soil: Effect on Crop Growth, Water Retention and Selected Properties. Agronomy 2019, 9 (6), 327. https://doi.org/10.3390/agronomy9060327.

(231) Munda, S.; Bhaduri, D.; Mohanty, S.; Chatterjee, D.; Tripathi, R.; Shahid, M.; Kumar, U.; Bhattacharyya, P.; Kumar, A.; Adak, T.; Jangde, H. K.; Nayak, A. K. Dynamics of Soil Organic Carbon Mineralization and C Fractions in Paddy Soil on Application of Rice Husk Biochar. Biomass and Bioenergy 2018, 115, 1-9. https://doi.org/10.1016/J.BIOMBIOE.2018.04.002.

(232) Faria, W. M.; Figueiredo, C. C. de; Coser, T. R.; Vale, A. T.; Schneider, B. G. Is Sewage Sludge Biochar Capable of Replacing Inorganic Fertilizers for Corn Production? Evidence from a Two-Year Field Experiment. Arch. Agron. Soil Sci. 2018, 64 (4), 505-519. https://doi.org/10.1080/03650340.2017.1360488.

(233) Sarma, B.; Borkotoki, B.; Narzari, R.; Kataki, R.; Gogoi, N. Organic Amendments: Effect on Carbon Mineralization and Crop Productivity in Acidic Soil. J. Clean. Prod. 2017, 152, 157-166. https://doi.org/10.1016/j.jclepro.2017.03.124.

(234) Velez, T. I.; Moonilall, N. I.; Reed, S.; Jayachandran, K.; Scinto, L. J. Impact of Melaleuca Quinquenervia Biochar on Phaseolus Vulgaris Growth, Soil Nutrients, and Microbial Gas Flux. J. Environ. Qual. 2018, 47 (6), 1487-1495. https://doi.org/10.2134/jeq2017.12.0484.

(235) Takaragawa, H.; Yabuta, S.; Watanabe, K.; Kawamitsu, Y. Effects of Application of Bagasseand Sunflower Residue-Derived Biochar to Soil on Growth and Yield of Oilseed Sunflower. 
Trop. Agric. Dev. 2017, 61 (1), 32-39. https://doi.org/10.11248/jsta.61.32.

(236) Hood-Nowotny, R.; Watzinger, A.; Wawra, A.; Soja, G. The Impact of Biochar Incorporation on Inorganic Nitrogen Fertilizer Plant Uptake; An Opportunity for Carbon Sequestration in $\begin{array}{llllll}\text { Temperate } \quad \text { Agriculture. } & \text { Geosciences }\end{array}$ https://doi.org/10.3390/geosciences8110420.

(237) Artiola, J. F.; Rasmussen, C.; Freitas, R. Effects of a Biochar-Amended Alkaline Soil on the Growth of Romaine Lettuce and Bermudagrass. Soil Sci. 2012, 177 (9), 561-570. https://doi.org/10.1097/SS.0b013e31826ba908.

(238) Trupiano, D.; Cocozza, C.; Baronti, S.; Amendola, C.; Vaccari, F. P.; Lustrato, G.; Di Lonardo, S.; Fantasma, F.; Tognetti, R.; Scippa, G. S. The Effects of Biochar and Its Combination with Compost on Lettuce (Lactuca Sativa L.) Growth, Soil Properties, and Soil Microbial Activity and Abundance. Int. J. Agron. 2017, 2017, 3158207. https://doi.org/10.1155/2017/3158207.

(239) Azeem, M.; Hayat, R.; Hussain, Q.; Ahmed, M.; Pan, G.; Ibrahim Tahir, M.; Imran, M.; Irfan, M.; Mehmood-ul-Hassan. Biochar Improves Soil Quality and N2-Fixation and Reduces Net Ecosystem CO2 Exchange in a Dryland Legume-Cereal Cropping System. Soil Tillage Res. 2019, 186, 172-182. https://doi.org/10.1016/j.still.2018.10.007.

(240) Rezaie, N.; Razzaghi, F.; Sepaskhah, A. R. Different Levels of Irrigation Water Salinity and Biochar Influence on Faba Bean Yield, Water Productivity, and Ions Uptake. Commun. Soil Sci. Plant Anal. 2019, 50 (5), 611-626. https://doi.org/10.1080/00103624.2019.1574809.

(241) El-Naggar, A.; El-Naggar, A. H.; Shaheen, S. M.; Sarkar, B.; Chang, S. X.; Tsang, D. C. W.; Rinklebe, J.; Ok, Y. S. Biochar Composition-Dependent Impacts on Soil Nutrient Release, Carbon Mineralization, and Potential Environmental Risk: A Review. Journal of Environmental Management. Academic Press July 1, 2019, pp 458-467. https://doi.org/10.1016/j.jenvman.2019.02.044.

(242) Lima, I.; P.M. JR, W. Sugarcane Bagasse and Leaf Residue Biochars as Soil Amendment for Increased Sugar and Cane Yields. Int. Sugar J. 2017, 119.

(243) Ogbe, V. B.; Jayeoba, O. J.; Amana, S. M. Effect of Rice Husk as an Amendment On The Physico-Chemical Properties of Sandy-Loam Soil In Lafia, Southern-Guinea Savannah, Nigeria. Prod. Agric. Technol. 2015, 11 (1), 44-55. https://doi.org/10.5923/j.env.20180801.03.

(244) Farrell, M.; Macdonald, L. M.; Butler, G.; Chirino-Valle, I.; Condron, L. M. Biochar and Fertiliser Applications Influence Phosphorus Fractionation and Wheat Yield. Biol. Fertil. Soils 2014, 50 (1), 169-178. https://doi.org/10.1007/s00374-013-0845-z.

(245) Marra, R.; Vinale, F.; Cesarano, G.; Lombardi, N.; d'Errico, G.; Crasto, A.; Mazzei, P.; Piccolo, A.; Incerti, G.; Woo, S. L.; Scala, F.; Bonanomi, G. Biochars from Olive Mill Waste Have Contrasting Effects on Plants, Fungi and Phytoparasitic Nematodes. PLoS One 2018, 13 (6), e0198728. https://doi.org/10.1371/journal.pone.0198728.

(246) Intani, K.; Latif, S.; Islam, M.; Müller, J. Phytotoxicity of Corncob Biochar before and after Heat Treatment and Washing. Sustainability 2018, 11 (1), 30. https://doi.org/10.3390/su11010030.

(247) Paetsch, L.; Mueller, C. W.; Kögel-Knabner, I.; Von Lützow, M.; Girardin, C.; Rumpel, C. Effect of In-Situ Aged and Fresh Biochar on Soil Hydraulic Conditions and Microbial C Use under Drought Conditions. Sci. Rep. 2018, 8 (1). https://doi.org/10.1038/s41598-018-25039-x.

(248) Hersh, B.; Mirkouei, A.; Sessions, J.; Rezaie, B.; You, Y. A Review and Future Directions on Enhancing Sustainability Benefits across Food-Energy-Water Systems: The Potential Role of 
Biochar-Derived Products. AIMS Environ. Sci. 2019, $6 \quad$ (5), $379-416$. https://doi.org/10.3934/environsci.2019.5.379.

(249) Wang, F.; Liu, Y.; Li, X.; Liu, F. Effects of Biochar Amendment, Co2 Elevation and Drought on Leaf Gas EXCHANGE, BIOMASS PRODUCTION AND WATER USE EFFICIENCY IN MAIZE. Pakistan J. Bot. 2018, 50 (4), 1347-1353.

(250) Rajapaksha, A. U.; Chen, S. S.; Tsang, D. C. W.; Zhang, M.; Vithanage, M.; Mandal, S.; Gao, B.; Bolan, N. S.; Ok, Y.S. Engineered/Designer Biochar for Contaminant Removal/Immobilization from Soil and Water: Potential and Implication of Biochar Modification. Chemosphere. Elsevier Ltd April 1, 2016, pp 276-291. https://doi.org/10.1016/j.chemosphere.2016.01.043.

(251) Ok, Y. S.; Tsang, D. C. W.; Bolan, N.; Novak, J. M. Biochar from Biomass and Waste: Fundamentals and Applications - Google Books https://books.google.com/books?hl=en\&lr=\&id=Twl2DwAAQBAJ\&oi=fnd\&pg=PP1\&dq=des igner+biochar+crop+agriculture\&ots=YVsW2Nnf6a\&sig=z6aKW5qdJ3IDpq5AzMEUPyDR3J $\mathrm{A} \# \mathrm{v}=$ onepage\&q=designer biochar crop agriculture\&f=false (accessed Jan 7, 2020). https://doi.org/https://doi.org/10.1016/C2016-0-01974-5.

(252) Novak, J. M.; Johnson, M. G.; Spokas, K. A. Concentration and Release of Phosphorus and Potassium From Lignocellulosic- and Manure-Based Biochars for Fertilizer Reuse. Front. Sustain. Food Syst. 2018, 2, 54. https://doi.org/10.3389/fsufs.2018.00054.

(253) Al-Wabel, M. I.; Hussain, Q.; Usman, A. R. A.; Ahmad, M.; Abduljabbar, A.; Sallam, A. S.; Ok, Y. S. Impact of Biochar Properties on Soil Conditions and Agricultural Sustainability: A Review. L. Degrad. Dev. 2018, 29 (7), 2124-2161. https://doi.org/10.1002/ldr.2829.

(254) Nair, A.; Lang, K.; Snyder, D. Impact of Biochar and Fertility Management on Potato Production; 2018. https://doi.org/10.31274/farmprogressreports-180814-2038.

(255) Youssef, M.; Al-Easily, I. A. S.; A.S. Nawar, D. Impact of Biochar Addition on Productivity and Tubers Quality of Some Potato Cultivars Under Sandy Soil Conditions. Egypt. J. Hortic. 2017, 44 (2), 199-217. https://doi.org/10.21608/ejoh.2018.2149.1030.

(256) Gámiz, B.; Velarde, P.; Spokas, K. A.; Celis, R.; Cox, L. Changes in Sorption and Bioavailability of Herbicides in Soil Amended with Fresh and Aged Biochar. Geoderma 2019, 337, 341-349. https://doi.org/10.1016/j.geoderma.2018.09.033. 